
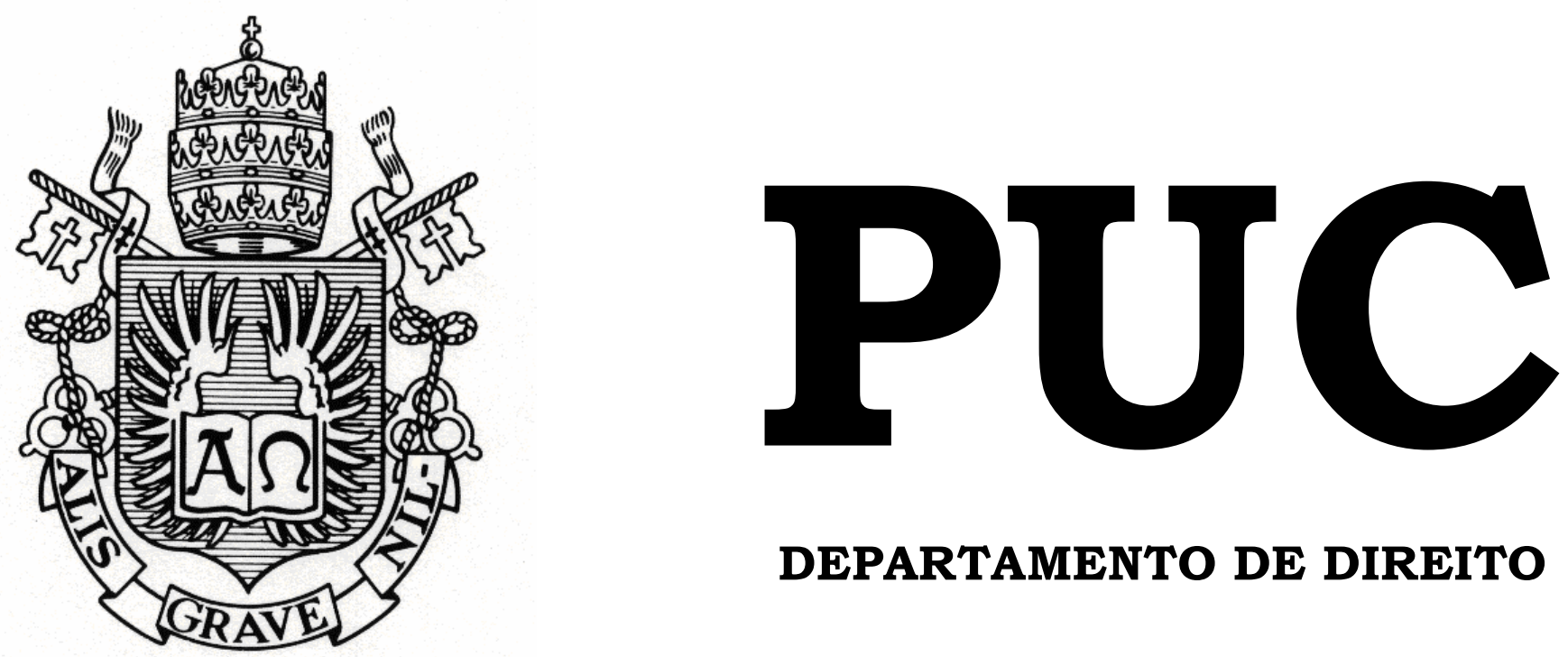

DEPARTAMENTO DE DIREITO

\title{
A REDUÇÃO DO MONTANTE INDENIZATÓRIO EM RAZÃO DA DESPROPORÇÃO ENTRE O GRAU DE CULPA E A EXTENSÃO DO DANO
}

\author{
por
}

GUILHERME DE SOUZA COSTA FRANQUEIRA

ORIENTADORA: MARIA CELINA BODIN DE MORAES

2007.2

PONTIFÍCIA UNIVERSIDADE CATÓLICA DO RIO DE JANEIRO

RUA MARQUÊS DE SÃO VICENTE, 225 - CEP 22453-900

RIO DE JANEIRO - BRASIL 


\title{
A REDUÇÃO DO MONTANTE INDENIZATÓRIO EM RAZÃO DA DESPROPORÇÃO ENTRE O GRAU DE CULPA E A EXTENSÃO DO DANO
}

\author{
por \\ GUILHERME DE SOUZA COSTA FRANQUEIRA
}

Monografia

apresentada

ao

Departamento de Direito da Pontificia Universidade Católica do Rio de Janeiro (PUC-Rio) para a obtenção do Título de Bacharel em Direito.

Orientadora: Maria Celina Bodin de Moraes 
Aos meus pais, que, depois de Freud, serão sempre os culpados. 

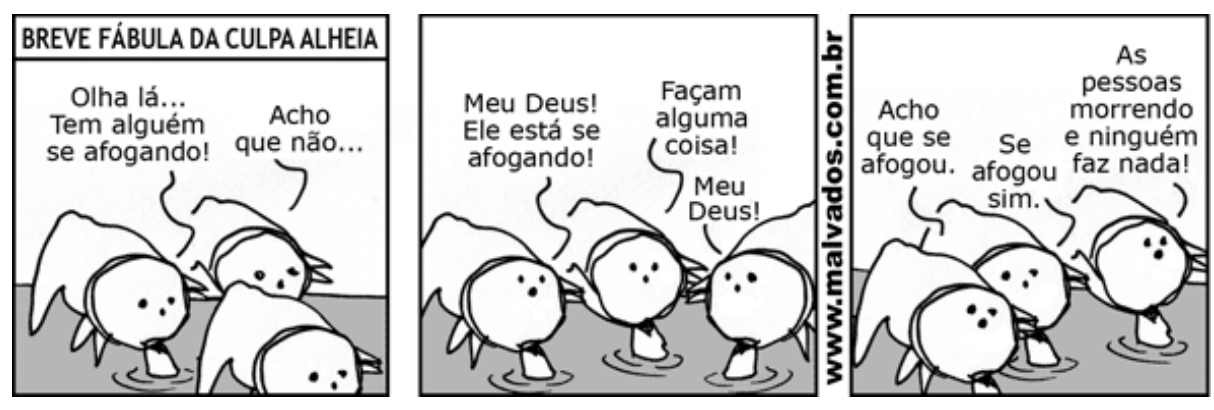

- André Dahmer

"Os Malvados" 


\section{AGRADECIMENTOS}

Esta monografia, embora redigida individualmente, é, na verdade, obra de diversos autores. Inúmeras mãos, olhares e leituras correram estas páginas, ajudando a compor o resultado final deste estudo. Sinceramente, agradeço:

Ao Professor Marcelo Junqueira Calixto, de quem partiu a maior das contribuições. Tive a oportunidade de, a seu lado, estudar a responsabilidade civil por dois anos de pesquisa de iniciação científica, e esta monografia é um dos reflexos de nosso esforço conjunto, a irmã caçula de uma robusta tese de doutorado, agora transposta em livro, da qual tomei parte como interlocutor e revisor. Agradeço imensamente a orientação e a generosidade.

Ao apoio dos Professores Maria Celina Bodin de Moraes, Caitlin Sampaio Mulholland e, mais uma vez, Marcelo Junqueira Calixto, e do amigo João Paulo Porto Rocha Souza, com os quais me aprofundei nos estudos do direito civil constitucional, por dois anos de pesquisa, em um grupo de estudos extracurricular, levado adiante apenas pelo nosso esforço comum, pelo bom humor e pela disposição de enfrentar as adversidades no percurso.

À Professora Kátia Regina da Costa Silva Ciotola, de quem sou devedor das palavras de incentivo, dos bons momentos em companhia de um espírito livre e alegre, e, principalmente, do corajoso estímulo à reformulação completa pela qual passou este trabalho no curso de sua elaboração.

À Patrícia Regina Person, minha fiel companheira, amiga de todas as horas e parceira no crime, pela intensa participação nesta obra, pelo amor desinteressado, por sua independência, e por me dar forças para seguir em frente nos momentos em que o ânimo e a determinação fraquejaram.

À Leda Hakym-Baba, Ledinha para os amigos próximos, por me fazer acreditar que a vida é, também, uma experiência estética, pelas boas maneiras, por sua doçura e temperança, qualidades que fazem da amizade um verdadeiro encantamento. 
À Mariana Villela Capanema Garcia, $\mathrm{PhD}$, a mulher mais inteligente que jamais conheci, por incontáveis préstimos em trabalhos acadêmicos, como este, faltam-me palavras para agradecer o incondicional apoio e a presença constante.

À minha avó, Norma, acima de tudo por sua generosidade, mas também pelo carinho de sempre e pelas orações constantes. Ao meu pai, Antonio, por tudo o que fez e pelo tanto mais que ofereceu, principalmente nos momentos difíceis. À minha mãe, Vera, prova viva de que mesmo as coisas muito simples permitem chegar à felicidade. À minha irmã, Mariana (rectius, Zum), que, em um de seus momentos de inclinação filosófica, cunhou a expressão "toda essa porra jurídica”, essencial aos momentos de frustração.

Aos muitos amigos da graduação, que cooperaram de maneiras distintas, uns me afastando destas páginas, quando necessário, outros me incentivando a continuar a redigi-las, em especial, Carla Wainer Chalréo Lgow, Clarice Cabral Cezar, Daniel de Andrade Lévy, Fernanda de Mattos Pinto da Silva, Gabriela Almeida de Moura Estevão e, mais uma vez, João Paulo Porto Rocha Souza.

A Deus. Estamos começando a nos entender, eu e Ele. 


\section{RESUMO}

O estudo que se segue é uma análise fundamentada do parágrafo único do artigo 944 do atual Código Civil brasileiro. Inicialmente, se oferece uma compilação doutrinária referente ao instituto legal da culpa, oferecendo a base teórica de todo o trabalho. Então, se proporciona uma investigação acerca da axiologia constitucional e de seus subseqüentes efeitos no direito privado e, em especial, na responsabilidade civil. Finalmente, procede-se ao efetivo escrutínio do dispositivo legal, concentrando-se na significação geral da estipulação; na avaliação de seu conteúdo textual, expurgando quaisquer dúvidas que nasçam de seus termos; no oferecimento de meios para a sua correta interpretação; no delineamento de sua aplicabilidade, determinando, destarte, o seu alcance; e na discussão de sua controversa constitucionalidade. 


\begin{abstract}
The following study is a sound analysis of the single paragraph of article 944 of the current Brazilian Civil Code. Initially, it offers a doctrinary compilation regarding the legal institute of negligence, laying the theoretical grounds of the entire paper. Then, it provides an investigation into the Constitutional axiology and its ensuing effects upon private law and, specifically, the law of torts. Finally, it proceeds to the actual scrutiny of the legal disposition, focusing on the overall significance of the stipulation; the evaluation of its textual content, expurgating any doubts the may arise from its terms; the endowing of means to its accurate interpretation; the delineation of its applicability, determining, therefore, its reach; and the thorough discussion of its controversial constitutionality.
\end{abstract}




\section{PALAVRAS-CHAVE}

Direito Civil. Direito Civil Constitucional. Responsabilidade Civil. Dignidade

Humana. Culpa. Dano. Indenização. Quantum Debeatur. Reparação Integral.

Excessiva desproporção. Redução. Hermenêutica. Sistemática. Eqüidade.

Ponderação de Princípios. Constitucionalidade. Artigo 944, § único, CC/2002. 


\section{SUMÁRIO}

\section{A REDUÇÃO DO MONTANTE INDENIZATÓRIO EM RAZÃO DA DESPROPORÇÃO ENTRE O GRAU DE CULPA E A EXTENSÂO DO DANO}

Introdução - Proposta de trabalho ............................................ 10

Capítulo 1 - 0 instituto da culpa ................................................ 14

1.1 - O conceito de culpa ............................................................ 14

1.2 - As espécies de culpa ........................................................ 18

1.3 - Os graus de culpa ............................................................... 21

Capítulo 2 - A axiologia constitucional e a responsabilidade

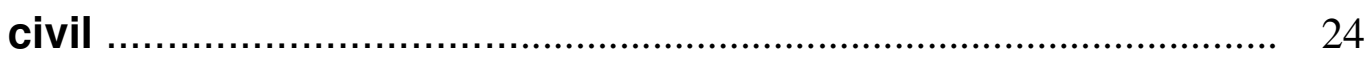

2.1 - A constitucionalização do direito privado ................................ 24

2.2 - Implicações da axiologia constitucional à responsabilidade

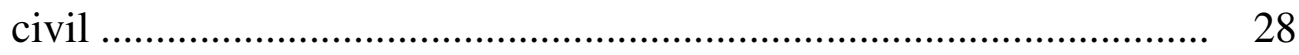

2.3 - O princípio da reparação integral ............................................. 33

Capítulo 3 - O Código Civil de 2002 e a inovação trazida pelo parágrafo único do artigo 944 ..................................................... 39

3.1 - A inteligência do dispositivo ................................................ 39

3.2 - A literalidade do dispositivo .................................................. 41

3.2 .1 - Gravidade da culpa .................................................... 41

3.2.2 - Excessiva desproporção ……………………………....... 47

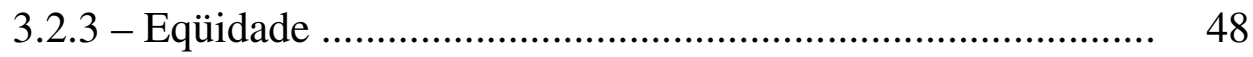

3.3 - A interpretação do dispositivo ............................................... 50

3.4 - A aplicabilidade do dispositivo ........................................... 53

3.4.1 - Responsabilidade civil subjetiva e objetiva …………....... 53

3.4.2 - Dano patrimonial e extrapatrimonial ................................ 55

3.5 - A constitucionalidade do dispositivo ....................................... 61

Conclusão - Síntese de idéias e considerações finais ............. 66

Bibliografia ................................................................. 71 


\section{Introdução - Proposta de trabalho}

O objetivo desta monografia é trabalhar uma das inovações trazidas ao sistema de responsabilidade civil pelo Código Civil de 2002, em específico, a partir da introdução, no parágrafo único do artigo 944, da possibilidade de se excetuar o princípio da reparação integral, que, em regra, informa o processo de quantificação indenizatória, em hipóteses de excessiva desproporção entre o grau da culpa do agente e a extensão do dano.

Para isso, dividiu-se a análise em três pontos, destinando-se o primeiro capítulo ao debate do instituto da culpa: definição, espécies e graus; o segundo, à contextualização do sistema de responsabilidade civil no ordenamento, a partir da tábua axiológica constitucional; e, finalmente, o terceiro, ao estudo aprofundado do objeto principal desta monografia, o parágrafo único do artigo 944 do Código Civil de 2002.

Inicia-se o trabalho pela análise doutrinária do instituto da culpa, a partir de seu conceito jurídico. Discute-se a dificuldade dogmática em se encontrar definição pacífica para o instituto, evidenciando a sua complexidade e suas múltiplas acepções, com especial atenção dedicada à histórica concepção psicológica de culpa e à noção normativa do instituto, que melhor se adapta ao sistema de responsabilidade civil contemporâneo. Pretende-se, então, avaliar as espécies da culpa, o dolo e a culpa em sentido estrito, para, finalmente, operadas as necessárias distinções, poder prosseguir-se rumo ao último ponto deste capítulo, a discussão dos graus da culpa - grave, leve e levíssima -, que se mostrará essencial, posteriormente, quando do estudo da literalidade do parágrafo único do artigo 944.

Uma vez que se tenha oferecido esta base teórica do instituto da culpa, é o momento de se operar a contextualização da norma e, em verdade, de todo o sistema de responsabilidade civil, em face ao ordenamento brasileiro, a partir das diretrizes principiológicas da Constituição da República, de 1988. 
Refuta-se, de imediato, entendimento defendido por parte da doutrina, a qual entende que, em virtude de o Código Civil de 2002 ter sido promulgado posteriormente à Constituição da República de 1988, ele, automaticamente, já se encontra em conformidade com o texto magno, e que desnecessários, por serem redundantes, seriam, portanto, os esforços do direito civil constitucional de conformar a dogmática privatista à preceituação constitucional ${ }^{1}$.

Não se adere a esta perspectiva por se a ter como um reducionismo. A metodologia do direito civil constitucional não se esgota numa avaliação do ordenamento a partir de sua estrutura hierárquico-temporal, mas encontra sua força no reconhecimento da importância da tábua axiológica constitucional como adequada a informar todo o ordenamento, inclusive o direito privado, a partir de valores positivados pelo legislador constituinte como tradução e síntese jurídica do espírito e da cultura do povo brasileiro ${ }^{2}$. Ainda mais, sabese que o novo Código Civil, apesar de promulgado no século XXI, em verdade, remonta à década 1970, quando originalmente se concebeu o seu anteprojeto. É lei que nasce, portanto, em muitos aspectos, já datada ${ }^{3}$.

Desta maneira, à melhor interpretação dos institutos do direito privado ainda compete sujeitar o diploma civilista a uma leitura em conformidade com

\footnotetext{
${ }^{1}$ AMARAL, Francisco. Direito Civil: Introdução. 6a Ed. Rio de Janeiro: Renovar, 2006. p. 156/157: "Em 12 de janeiro de 2003 entra em vigor o novo Código Civil brasileiro, como lei básica, mas não global, do nosso direito privado. Dispondo no seu artigo $1^{\circ}$ que toda pessoa é capaz de direitos $e$ deveres na ordem civil, estabelece-se como âmbito prioritário de eficácia dos direitos, pretensões e ações de natureza civil, o que deve levar ao refluxo a idéia de constitucionalização do direito civil" (grifos no original).

${ }^{2}$ TEPEDINO, Gustavo. O Código Civil e o Direito Civil Constitucional. In: TEPEDINO, Gustavo. Temas de Direito Civil. Tomo I. Rio de Janeiro: Renovar, 2006. p. 377/378: “A perspectiva do Direito Civil Constitucional, porém, mostra-se muito mais ampla do que decorreria de um estéril debate em torno da reorganização topográfica do sistema. São os valores expressos pelo legislador constituinte que, extraídos da cultura, da consciência social, do ideário ético e da noção de justiça presentes na sociedade, consubstanciam-se em princípios, os quais devem informar o sistema como um todo e, especialmente, o Código Civil" (grifos no original).

3 Id. O Novo Código Civil: duro golpe na recente experiência constitucional brasileira. In: TEPEDINO, Gustavo. Temas de Direito Civil. Tomo II. Rio de Janeiro: Renovar, 2006. p. 358: “o novo Código nascerá velho principalmente por não levar em conta a história constitucional brasileira e a corajosa experiência jurisprudencial, que protegem a personalidade humana mais do que a propriedade, o ser mais do que o ter, os valores existenciais mais do que os patrimoniais. E é demagógico porque, engenheiro de obras feitas, pretende consagrar direitos que, na verdade, estão tutelados em nossa cultura jurídica pelo menos desde o pacto político de outubro de 1988".
} 
os preceitos cristalizados na tábua axiológica constitucional. Cumprindo esta premissa, inaugura-se o segundo capítulo com a investigação do processo de constitucionalização do direito privado. A partir daí, procurar-se-á relatar as implicações deste processo de constitucionalização especificamente no que tange à responsabilidade civil, dedicando-se especial atenção ao princípio da reparação integral, refletindo-se acerca da importância que este assume dentro de uma sistemática cujo centro é a cláusula geral de tutela da dignidade da pessoa, consagrando, em definitivo, a prevalência das relações existenciais ante as patrimoniais.

Procede-se, então, finalmente, à apreciação do parágrafo único do artigo 944, o elemento central deste estudo. Para a melhor compreensão do preceito, propõe-se a análise segmentada do mesmo, discorrendo, sucessivamente, a respeito da inteligência do dispositivo, de sua literalidade e interpretação, dos limites de sua aplicabilidade e de sua constitucionalidade.

Ao tratar da inteligência da norma, pretende-se traçar um entendimento panorâmico de seu conteúdo, oferecendo os contornos materiais da norma, bem como referir-se aos princípios da matriz constitucional que devem orientar a sua aplicação.

Ao avaliar a literalidade do preceito, serão observados os termos empregados pelo legislador ao compor a dicção do parágrafo único, com destaque ao critério da "excessiva desproporção", o parâmetro da "gravidade da culpa", e a eqüidade que deve pautar a discricionariedade do magistrado.

Quanto à interpretação da norma, pretende caracterizar-se, a partir dos ditames da hermenêutica, o melhor método interpretativo a ser utilizado para promover a devida adequação do parágrafo único ao caput, bem como conformar a norma aos princípios que a informam. Neste espectro, pretende avaliar-se, também, a possibilidade de interpretações extensivas, que tragam novas possibilidades de limitação do quantum indenizatório a partir de outros critérios que não apenas o legal, bem como de interpretações a contrario sensu, 
que procurem no dispositivo o reconhecimento normativo do caráter punitivo da responsabilidade civil.

Em referência ao escopo de aplicabilidade da disposição, a discussão abrange dois tópicos: inicialmente, determinar se deve restringir-se a norma a apenas uma esfera da responsabilidade civil, ou se ela se aplica indistintamente a ambas responsabilidade civil objetiva e subjetiva; seqüencialmente, estudar em quais hipóteses de danos tem aplicação o preceito: se apenas nos danos patrimoniais, se exclusivamente nos danos extrapatrimoniais, ou se a ambas as espécies de prejuízo, sem diferenciação.

Encerrando o terceiro capítulo, virá a apreciação da constitucionalidade do parágrafo único do artigo 944, a qual é questionada por alguns em razão de a norma trazer uma mitigação do princípio da reparação integral, que tem status de princípio constitucional implícito, priorizando a figura do agente causador do dano, ao revés da vítima, que terá, ela própria, de arcar com parte do ônus pelo prejuízo sofrido.

Finalmente, ao longo da conclusão, procura-se oferecer uma síntese dos principais pontos referidos ao longo desta exposição. Pretende-se, ao final, que se tenha delineado, com clareza e segurança, a atual e adequada situação do parágrafo único do artigo 944 do Código Civil de 2002 perante o ordenamento, estabelecidas premissas para a sua melhor interpretação e aplicação. 


\section{Capítulo 1 - 0 instituto da culpa}

\section{1 - O conceito de culpa}

O instituto da culpa é absolutamente fundamental à atual dogmática da responsabilidade civil pátria, pois o Código Civil brasileiro o coloca como elemento caracterizador do ato ilícito, conforme se depreende da dicção do artigo 186, o qual determina que, para que ocorra um ilícito civil, é necessária a intenção, a negligência ou a imprudência do agente ao violar o direito alheio e lhe causar dano. A verificação da culpa, portanto, consubstancia-se na análise valorativa da conduta do agente e, em razão disto, a responsabilidade civil fundada neste conceito é reputada subjetiva ${ }^{4}$.

No sistema de responsabilidade civil subjetiva, a culpa pode ser interpretada como um filtro, separando a conduta à qual se atrela a obrigação de indenizar daquela livre do dever de reparar. Neste cenário, o sistema tem um forte caráter moralizador, pois é apenas a conduta eivada de culpa que sofre o juízo de reprovação social e a conseqüente censura jurídica ${ }^{5}$. A lógica do sistema, neste ponto, está distante dos interesses da vítima ${ }^{6}$, preocupando-se o ordenamento, pelo contrário, em discernir, dentre as condutas sociais possíveis, quais as moralmente aceitáveis e quais as reprováveis ${ }^{7}$.

\footnotetext{
${ }^{4}$ TEPEDINO, Gustavo et al. Código Civil interpretado conforme a Constituição da República. vol. I. Rio de Janeiro: Renovar, 2004. p. 333: "A responsabilidade por ato ilícito depende da verificação de dolo ou culpa por parte do agente, que é um dos elementos dogmáticos do ato ilícito. Exige-se que, no momento da conduta, o sujeito tenha tido a intenção de causar o prejuízo (dolo) ou o tenha causado por agir com menos cuidado que o esperado (culpa). A verificação da culpa ou dolo - noções reunidas sob a denominação de culpa lato sensu - depende de uma valoração da conduta do sujeito, daí chamar-se de responsabilidade subjetiva aquela responsabilidade fundada na culpa" (grifos no original).

${ }^{5}$ VARELA, João de Matos Antunes. Das Obrigações em Geral. $7^{\mathrm{a}}$ Ed. Coimbra: Almedina, 1991. p. 554: "Para que o facto ilícito gere responsabilidade, é necessário que o autor tenha agido com culpa. (...) Agir com culpa significa actuar em termos de a conduta do agente merecer a reprovação ou censura do direito." (grifos no original).

${ }^{6}$ Acerca do giro conceitual pelo qual passou a dogmática civilista brasileira e dos reflexos da axiologia constitucional na responsabilidade civil, entre eles, a proeminência da figura da vítima, discorrer-se-á no Capítulo 2, infra.

${ }^{7}$ FILHO, Sérgio Cavalieri. Programa de Responsabilidade Civil. 5a Ed. São Paulo: Malheiros, 2004. p. 48: "Nem todo comportamento do agente está apto a gerar o dever de indenizar, mas somente aquele que estiver revestido de certas características previstas na ordem jurídica. A vítima de um dano só poderá pleitear ressarcimento de alguém se conseguir provar que esse alguém agiu com culpa; caso
} 
Apesar de sua importância, o conceito de culpa tem, historicamente, trazido dificuldades à doutrina privatista, tanto que ainda hoje falta definição pacificada na literatura jurídica, capaz de apreender as nuances a que se presta o instituto ${ }^{8}$. De maneira inegável coloca-se o fato de que, a despeito de sua recorrente aplicabilidade - eis que o instituto praticamente operou como único e exclusivo nexo de imputação de responsabilidade civil ao agente por dezenas de séculos - e de sua integração à sistemática do ordenamento, o conceito jurídico de culpa, mesmo hoje, permanece abrumado 9 .

A discussão gira ao redor de dois pólos, duas concepções distintas do conceito de culpa ${ }^{10}$, uma de natureza psicológica, chamada culpa subjetiva, que enxerga no instituto a violação de dever legal ou contratual preexistente; e outra de matiz normativo, dita culpa objetiva, que entende por culposa a

contrário, terá que conformar-se com a sua má sorte e sozinha suportar o prejuízo. Vem daí a observação: 'a irresponsabilidade é a regra, a responsabilidade a exceção' (De Page)”.

${ }^{8}$ Quanto à multiplicidade de acepções que se pode encontrar para o conceito de culpa nos diversos Ordenamentos jurídicos do Mundo e da História, imprescindíveis os dizeres de GONÇALVES, Luiz da Cunha. Tratado de Direito Civil em Comentário ao Código Civil Português. vol. XII. Tomo II. $1^{\mathrm{a}}$ Ed. São Paulo: Max Limonad, 1957. p. 584: "A palavra "culpa" não tem só dois sentidos, como dizem alguns dos supracitados escritores, mas sim quatro ou cinco. Assim: a) no sentido clássico do direito romano, culpa é toda a violação do direito alheio, cometida sine jure ou contra jure, é a injúria; b) no sentido do direito romano justinianeu e, sobretudo, dos jurisconsultos dos séculos XVII, XVIII e XIX, culpa é a atividade voluntária ou moralmente imputável, com ou sem intenção de lesar, mas de que resultou prejuízo, quer de outrem, quer da própria pessoa que a exerceu; c) num sentido mais restrito, culpa é toda e qualquer falta de diligência ou negligência sem propósito de lesar, mas de que resultou dano de outrem ou ofensa de direitos alheios, distinguindo-se do dolo em que neste existe o propósito de lesar; d) num sentido especial, culpa é toda a conduta contrária ao pontual cumprimento duma obrigação" (grifos no original).

${ }^{9}$ DIAS, José de Aguiar. Da Responsabilidade Civil. vol. I. $7^{\mathrm{a}}$ Ed. Rio de Janeiro: Forense, 1983. p. 115: "É tão difícil definir a culpa, que muitos mestres negam a própria possibilidade de o fazer. Ripert é, a este respeito, muito expressivo, pois sustenta, sem disfarce, que não há definição legal da culpa, que não se pode, mesmo, tentar formulá-la". Afirmando a existência de uma "floresta de definições, que mais extensa fora, quanto mais se levasse a pesquisa", há PEREIRA, Caio Mario da Silva. Responsabilidade Civil. $9^{a}$ Ed. Rio de Janeiro: Forense, 1999. p 69. Também colacionando citações de diversos autores que encontraram dificuldade ao conceituar o instituto da culpa, ver STOCO, Rui. Tratado de Responsabilidade Civil. $6^{\text {a }}$ Ed. São Paulo: Revista dos Tribunais, 2004, p. 134.

${ }^{10}$ MORAES, Maria Celina Bodin de. Danos à Pessoa Humana: Uma Leitura Civil-Constitucional dos Danos Morais. Rio de Janeiro: Renovar, 2003. p. 209: "Tanto em doutrina nacional como em doutrina estrangeira discute-se ainda sobre a noção de culpa". E segue, em nota de referência de n. ${ }^{\circ}$ 408, na mesma página: "A discussão baseia-se, principalmente, na seguinte controvérsia: é imprescindível a existência de uma norma anterior específica, ou é suficiente a previsão genérica do neminem laedere para a determinação do comportamento ilícito". 
conduta desviante do padrão de comportamento socialmente esperado, em razão do princípio da boa-fé objetiva e da diligência média.

Originariamente, aproximava-se a noção de culpa à falha moral, tendo os doutrinadores medievos, inclusive, aproximado-a à noção canônica de pecado. A culpa era tida como uma falta moral do agente lesivo, daí reputada culpa psicológica, atrelando-se em definitivo à vontade da pessoa ${ }^{11}$. Culposa era a conduta que nascia da vontade do agente e cujo resultado danoso poderia ter sido previsto e deveria ter sido evitado pelo mesmo ${ }^{12}$. Nos termos desta construção teórica, a culpa estaria atrelada à violação de um dever jurídico preexistente, seja legal, seja contratual, sendo indispensável a livre e consciente manifestação de vontade do agente no sentido de lançar-se na conduta cujo resultado danoso poderia prever e deveria evitar ${ }^{13}$.

As críticas mais corriqueiras a esta concepção do conceito de culpa concerniam à dificuldade probatória da sua caracterização ${ }^{14} \mathrm{e}$, principalmente, à dependência da preexistência de um dever legal ou contratual a ser violado, o que, na prática, nem sempre existia ${ }^{15}$.

\footnotetext{
11 SCHREIBER, Anderson. Novas Tendências da Responsabilidade Civil Brasileira. In: Revista Trimestral de Direito Civil, vol. 06, n. ${ }^{\circ}$ 22, abr/jun 2005. p. 48: "Vinculada, originariamente, à idéia de pecado, a culpa era compreendida, antes do mais, como uma falta moral, indissociavelmente ligada aos impulsos anímicos do sujeito".

12 VARELA, João de Matos Antunes. Das Obrigações em Geral, p. 559: “A culpa exprime um juízo de reprovabilidade da conduta do agente: o lesante, em face das circunstâncias específicas do caso, devia e podia ter agido de outro modo. É um juízo que assenta no nexo existente entre o facto e a vontade do autor".

${ }^{13}$ MORAES, Maria Celina Bodin de. Danos à Pessoa Humana, p. 210: "A concepção subjetiva ou psicológica, chamada de concepção clássica, vê a culpa como violação de um dever preexistente, considerando, como aspecto essencial para a construção do conceito, a manifestação de vontade, livre e consciente, do agente, em relação à qual, surge, ou corresponde, um conseqüente juízo moral de condenação daquela ação. (...) Qualificando a vontade, há um outro elemento que se faz central: é o da previsibilidade do resultado, pressuposto lógico e psicológico de sua evitação".

${ }^{14}$ SCHREIBER, Anderson. Op. cit., p. 48: "Nesta acepção, a prova da culpa mostrava-se como se sabe, extremamente árdua, impondo juízos de previsibilidade do dano e análises psicológicas incompatíveis com os limites naturais da atividade judiciária".

${ }^{15}$ MORAES, Maria Celina Bodin de. Danos à Pessoa Humana, p. 210/211: "A mais incisiva crítica que se faz a tal noção é a de que, apesar de correta, é ela insuficiente, porque a conduta culposa, aqui, teria que decorrer de violação da lei ou do contrato (isto é, do dever preexistente), o que nem sempre acontece".
} 
Nos primórdios do século XX, concebeu-se, finalmente, uma nova acepção jurídica do termo "culpa”, ora de caráter normativo, a culpa nomeada objetiva, assim considerada como um erro de conduta ${ }^{16}$, um desvio do padrão de comportamento socialmente esperado, livre das amarras da violação de obrigação previamente estipulada em contrato ou em lei, atentando, assim, contra o dever jurídico genérico de não causar dano a outrem, o neminem laedere, oriundo da necessidade de se preservar a harmonia social pelo respeito à integridade das pessoas e de seus bens ${ }^{17}$. A adoção de um modelo de conduta abstrato, a conduta do homem médio, determinação dos parâmetros de cuidado e diligência a informar a apreciação do desvio culposo, portanto, é pedra de toque desta nova acepção teórica de culpa ${ }^{18}$. Admite-se, aliás, para evitar eventuais injustiças que possivelmente (rectius, inevitavelmente) decorreriam da adoção de um único padrão de comportamento humano, invariável e demasiadamente genérico, a particularização de tal modelo de conduta, adotando uma multiplicidade de standards específicos, mais adequados à resolução da questão concreta, desmembrando a conduta humana em diversas variáveis, operando, desta forma, uma especificação do parâmetro abstrato de comportamento, sem, entretanto, tolher a sua objetividade ${ }^{19}$.

\footnotetext{
${ }^{16}$ Ibid. p. 211.

17 FILHO, Sérgio Cavalieri. Op. cit., p. 53: “Ao lado do dever imposto por lei ou regulamento, resultante de um texto claro que obrigue a fazer ou deixar de fazer alguma coisa, há também um dever indeterminado que justifica as hipóteses em que a culpa existe sem que o dever corresponda a um texto expresso de lei ou regulamento. O ponto de partida da culpa, portanto, a sua ratio essendi, é a violação de uma norma de conduta por falta de cuidado; geral, quando contida na lei, particular, quando consignada em contrato, mas sempre por falta de cautela. E a observância desta norma é fator de harmonia social".

${ }^{18}$ MORAES, Maria Celina Bodin de. Danos à Pessoa Humana. p. 211: "Para esta corrente, a culpa seria um desvio do modelo de conduta representado pela boa-fé e pela diligência média, isto é, ação ou omissão que não teria sido praticada por pessoa prudente, diligente e cuidadosa, em iguais circunstâncias".

${ }^{19}$ SCHREIBER, Anderson. Op. cit., p. 52: "Daí verificar-se, por toda parte, um fenômeno que se poderia designar como fragmentação do modelo de conduta, ou seja, a utilização de parâmetros de conduta específicos e diferenciados para as diversas situações. Ao invés de se recorrer a um genérico e irreal bonus pater familias na avaliação da conduta quer de um médico acusado de erro profissional, quer de uma companhia acusada de divulgar balanços adulterados, o que se tende a adotar são parâmetros específicos (standards) de conduta para cada qual destas situações (...). Com isso, a prova da culpa deixa, cada vez mais, de pertencer ao juízo abstrato do magistrado, contando com parâmetros mais específicos, objetivos e seguros de aferição" (grifos no original).
} 
A tendência do sistema, atualmente, é a de suplantar, finalmente, esta dificuldade conceitual, suprimindo a noção psicológica de culpa, aderindo, afinal, à sua acepção normativa ${ }^{20}$. A culpa é um elemento central do sistema de responsabilidade civil, mas recebe nova roupagem e, neste sentido, melhor se amolda aos paradigmas do direito contemporâneo, conforme se verá no capítulo seguinte. Por ora, convém apenas reforçar que o conceito de culpa, aos olhos da melhor doutrina, atualmente corresponde ao descumprimento de um standard de conduta objetivamente considerado ${ }^{21}$.

\section{2 - As espécies de culpa}

Inicialmente, é oportuno informar que a culpa, como até agora referida, é a chamada culpa lato sensu, gênero a que correspondem duas espécies: dolo e culpa stricto sensu. Convém, finalmente, operar a distinção.

A culpa lato sensu, reitera-se, é um erro de conduta praticado pelo agente lesivo, o qual, ao proceder contra o direito, provoca dano a outrem ${ }^{22}$. Quando este resultado danoso era previsto e desejado (ou, ao menos, assumido) pelo agente lesivo, diz-se que este obrou em dolo; quando, embora previsível ao homem de média diligência, o resultado danoso não fora previsto, nem desejado, tem-se a culpa stricto $\operatorname{sensu}^{23}$.

Compreende-se o dolo como a conduta deliberadamente governada à produção de um resultado danoso, ilícito. Há a concreta previsão da produção do efeito lesivo e a consciente decisão, ainda assim, pelo empreendimento da

\footnotetext{
20 TEPEDINO, Gustavo et al. Código Civil interpretado conforme a Constituição da República. vol. I, p. 333: "Na verdade, não é o ilícito que se amplia, mas a noção de culpa que vem se objetivando, distanciando-se do conceito subjetivo de 'previsibilidade do resultado danoso' e caminhando, cada vez mais, para a idéia de violação a parâmetros objetivos".

${ }^{21}$ MORAES, Maria Celina Bodin de. Danos à Pessoa Humana, p. 212.

${ }^{22}$ PEREIRA, Caio Mario da Silva. Responsabilidade Civil, p. 69.

${ }^{23}$ DIAS, José de Aguiar, Op. cit., p. 113: "A conduta reprovável, por sua parte, compreende duas projeções: o dolo, no qual se identifica a vontade direta de prejudicar (...); e a simples negligência (negligencia, imprudentia, ignavia) em relação ao direito alheio, que vem a ser a culpa no sentido restrito".
} 
conduta $^{24}$. Quando a vontade do agente é causar o dano antevisto, diz-se que se caracteriza a figura do dolo direto. Contrariamente, quando o resultado danoso não é propriamente desejado pelo agente, mas este assume o risco de produzilo (em outras palavras, o azo do sujeito não é exatamente a produção do efeito lesivo, mas ele o prevê, sabe da probabilidade de se o provocar, e, ainda assim, insiste na conduta, abraçando o risco de ocasioná-lo), tem-se o dolo indireto, ou dolo eventual ${ }^{25}$.

Na culpa stricto sensu, por sua vez, o agente não tem a intenção de contrariar o direito, prejudicando outrem, porém seu comportamento está em desconformidade aos parâmetros socialmente esperados ${ }^{26}$. Quando a conduta do agente está aquém dos parâmetros socialmente exigíveis, quando ocorre a omissão daquilo que razoavelmente se espera, diz-se que há culpa stricto sensu, manifesta na figura da negligência ${ }^{27}$. Em outras palavras, negligente é a conduta descuidada, é o desmazelo, a inobservância da diligência socialmente

\footnotetext{
${ }^{24}$ FILHO, Sérgio Cavalieri. Op. cit., p. 50.

${ }^{25}$ A doutrina majoritária - tanto penalista, quanto civilista - trabalha com a noção dicotômica de dolo. Neste sentido, refere-se, com propósito meramente ilustrativo, às obras de GRECO, Rogério. Curso de Direito Penal. vol. I. Parte Geral: Artigos $1^{\circ}$ a 120 do Código Penal. $7^{\mathrm{a}}$ Ed. Rio de Janeiro: Impetus, 2006. p. 198 e ss.; e VENOSA, Sílvio de Salvo. Direito Civil. vol. I. Parte Geral. $3^{\text {a }}$ Ed. São Paulo: Atlas, 2003. p. 589 e ss., em especial p. 591/592. Há, contudo, autores que se filiam a corrente distinta, que defende a tripartição do instituto, incluindo a figura do dolo necessário, que corresponderia à situação em que o agente não tem por azo propriamente o resultado lesivo, mas este é conhecida e necessária conseqüência de sua conduta. Dentre os doutrinadores que se filiam a esta corrente, cumpre destacar, pelo peso de sua obra, a figura de VARELA, João de Matos Antunes. Das Obrigações em Geral, p. 562/563: "Ao lado destes casos [de dolo direto], embora com um recorte psicológico distinto, outros devem ser ainda incluídos no conceito de dolo, por suscitarem igual juízo de reprovação no plano do direito. São aqueles casos em que, não querendo directamente o facto ilícito, o agente todavia o previu como uma consequiência necessária, segura, da sua conduta. O efeito ilícito e o resultado querido estavam indissociavelmente ligados, o agente conhecia este nexo de causalidade, e nem por isso deixou de agir. (...) Os autores não hesitam em equiparar, quanto ao seu tratamento jurídico, o dolo necessário e o dolo directo" (grifos no original).

${ }^{26}$ PEREIRA, Caio Mario da Silva. Instituições de Direito Civil.vol. II. Teoria Geral das Obrigações. Atualização por GAMA, Guilherme Calmon Nogueira da. Rio de Janeiro: Forense, 2007. p. 366: “A culpa [stricto sensu] é a inobservância de uma conduta razoavelmente exigível para o caso concreto, tendo em vista padrões medianos. A ação é voluntária, no que diz respeito à materialidade do ato gerador das conseqüências danosas. Mas o agente não procura o dano como objetivo de sua conduta, nem procede com a consciência da infração".

${ }^{27}$ DIAS, José de Aguiar, Op. cit., p. 127: "Negligência é a omissão daquilo que razoavelmente se faz, ajustadas as condições emergentes às considerações que regem a conduta normal dos negócios humanos. É a inobservância das normas que nos ordenam operar com atenção, capacidade, solicitude e discernimento".
} 
esperada pela própria incúria do agente. Reversamente, quando o sujeito adota um comportamento que extrapola o modelo de agir esperado socialmente, novamente há culpa stricto sensu, ora manifesta na figura da imprudência ${ }^{28}$. Em síntese, imprudente é a conduta impetuosa, é o excesso, o descumprimento do comportamento socialmente aguardado em razão da precipitação do causador do dano.

Reportando-se ao dispositivo legal, o artigo 186 do atual Código Civil, percebe-se que o legislador, ao estatuir a cláusula geral de responsabilidade civil subjetiva, fundada no ato ilícito, já o fez com explícita distinção destas duas espécies: ao referir-se à conduta voluntária, está a tratar do dolo; ao mencionar negligência e imprudência, dirige-se às modalidades da culpa stricto sensu. É importante notar, entretanto, que o dispositivo não estipula tratamento diferenciado em razão de tal distinção, o que levou alguns autores a afirmar a inutilidade prática da mesma ${ }^{29}$. Trata-se, neste ponto, de conclusão precipitada, vez que outros dispositivos, tanto na seara contratual, quando no âmbito extracontratual, darão tratamento diferenciado ao ilícito, a depender de a conduta ser dolosa ou culposa ${ }^{30}$. Um deles é o parágrafo único do artigo 944

\footnotetext{
${ }^{28}$ Ibid. p. 127: "Consiste a imprudência na precipitação, no procedimento inconsiderado, sem cautela, em contradição com as normas do procedimento sensato. É a afoiteza no agir, o desprezo das cautelas que devemos tomar em nossos atos".

${ }^{29}$ FILHO, Sérgio Cavalieri. Op. cit., p. 49: "Para alguns, não há utilidade prática na distinção entre dolo e culpa, porquanto, pelo nosso Direito vigente, o agente responde igualmente pelas consequiências da sua conduta, sem se indagar se o resultado danoso entrou nas cogitações do infrator, ou se a violação foi especialmente querida". Neste mesmo sentido, a comentar o correspondente artigo 159 do Código Civil de 1916, DIAS, José de Aguiar, Op.cit., p. 127: "Nem mesmo a classificação dos atos ilícitos em dolosos ou culposos apresenta interesse para o civilista brasileiro, que só cogita do gênero ato ilícito" (grifos no original).

30 PEREIRA, Caio Mario da Silva. Instituições de Direito Civil. vol. II, p. 365: "Em certas circunstâncias, distingue-se entre o inadimplemento doloso e culposo, para definir a responsabilidade em casos especiais. Nos contratos onerosos, não é necessária a análise subjetiva da transgressão, visto como o contratante inadimplente responde por perdas e danos à simples demonstração de sua culpa Nos contratos benéficos, é que vem a menção do dolo, para se estabelecer que a responsabilidade do contratante inadimplente é uma função do elemento anímico: aquele a quem o contrato aproveita responde pela culpa, e só por dolo aquele a quem não favoreça (Código Civil de 2002, art. 392). Há, no entanto, casos em que a própria lei adota o grau de intensidade ou gravidade de culpa ora para redução da indenização (por manifesta desproporção com o dano), ora para seu arbitramento (no caso de concorrência de culpas), dentro do disposto nos arts. 944, parágrafo único, e 945, do Código Civil de 2002".
} 
do Código Civil, objeto central de discussão deste estudo, cuja aplicação se restringe às hipóteses de culpa stricto sensu, excluindo-se o dolo ${ }^{31}$.

\section{3 - Os graus de culpa}

Dogmaticamente, classifica-se também a culpa stricto sensu em função de seus graus. Três gradações são tradicionalmente levantadas pela doutrina ${ }^{32}$, quais sejam: culpa grave, culpa leve e culpa levíssima.

Tal graduação é oriunda do direito bizantino e originalmente referia-se à diligência adotada pelo agente e ao grau de previsibilidade do resultado lesivo, em direta conexão à postulação anímica do instituto. Desta forma, em culpa grave estaria o agente que falhou em antecipar algo que está em um escopo elementar de previsibilidade e em portar-se com o mínimo de diligência; em culpa leve estaria aquele que não anteviu o dano regularmente previsível e não se conduziu com a diligência esperada do homem médio ${ }^{33}$; e, por último, em culpa levíssima incorreria o sujeito a quem escapasse a ocorrência de dano que só seria calculado por pessoa dotada de excepcional previsibilidade e evitado por sujeito de diligência extraordinária ${ }^{34}$.

Contemporaneamente, uma vez que o conceito de culpa se objetiva, este critério de graduação não mais encontra abrigo. A graduação da culpa não mais se atrela a um paradigma psíquico, devendo partir do conceito normativo de erro de conduta, a partir de standards variáveis de comportamento, compatíveis

\footnotetext{
${ }^{31}$ STOCO, Rui. Op. cit., p. 141.

${ }^{32}$ A rigor, um conceito abstrato como o de culpa se presta a infinitas graduações, ao gosto de quem queira conjeturar a respeito. Dissertando a respeito deste tópico, diz GONÇALVES, Luiz da Cunha. Op. cit., p. 591: "já houve quem pretendesse estabelecer seis graus: latissima, latior, lata, levis, levior, levissima, - graduação que não teve êxito algum na doutrina; assim como outros quiseram reduzir os graus só a dois: lata e levis, o que não obteve melhor aceitação".

33 Conceituando a figura do "homem médio", preleciona VARELA, João de Matos Antunes. Das Obrigações em Geral, p. 567: "pelo modelo de homem-tipo, pelo padrão de um sujeito ideal, a que os romanos davam a designação prosaica de bonus pater famílias, e que é, no fundo, o tipo de homem médio ou normal que as leis têm em vista ao fixarem os direitos e deveres das pessoas em sociedade".

${ }^{34}$ Ibid. p. 570, nota de referência de . $^{\circ} 1$.
} 
com a atividade desempenhada ${ }^{35}$. Assim, em culpa grave age aquele cujo comportamento discrepa exageradamente do parâmetro de diligência confiado socialmente; em culpa leve está o sujeito cuja conduta escapa mitigadamente aos padrões de cuidado esperados; e em culpa levíssima opera aquele cuja atuação está no limiar da diligência e, por um pequeno desvio, acaba em falta com o zelo almejado ${ }^{36}$.

Quanto aos graus, comumente afirmava-se que não haveria distinção prática entre eles, para efeitos de responsabilidade civil, posto que, em igual medida, estaria obrigado à reparação o agente que obrasse em culpa grave, leve ou levíssima. Desta maneira, grande parte da doutrina considerava supérflua a $\operatorname{gradação~}^{37}$, mero exercício dogmático, pois, na prática, a demonstração de qualquer tipo de culpa já bastaria para caracterizar o ato ilícito, inexistindo qualquer tipo de tratamento normativo diferenciado, uma vez constituído o dever de reparar. Esta posição não mais se sustenta, em razão de o parágrafo único do artigo 944 do Código Civil de 2002 instituir expressa disposição legal em que, em função da excessiva desproporção entre a gravidade da culpa do agente e a extensão do dano provocado, estaria autorizado o juiz a promover equânime redução da monta indenizatória ${ }^{38}$. Não é mais possível argüir a inutilidade da dogmática concernente a estes graus ${ }^{39}$, pois, embora não se diferencie, no que tange estritamente ao nexo de imputação, o enquadramento da conduta em culpa levíssima, leve ou grave, no momento da estipulação do quantum debeatur, afinal, passará a análise do jurista pela sua apreciação.

\footnotetext{
${ }^{35}$ MORAES, Maria Celina Bodin de. Danos à Pessoa Humana, p. 213.

${ }^{36}$ Ibid. p. 216.

37 PEREIRA, Caio Mario da Silva. Responsabilidade Civil, p. 71: "Nosso direito desprezou esta gradação da culpa, que não deve influir na determinação da responsabilidade civil, e que não encontra amparo no BGB ou apoio em boa parte da doutrina".

38 TEPEDINO, Gustavo, et al. Código Civil interpretado conforme a Constituição da República. vol. II. Rio de Janeiro: Renovar, 2006. p. 860: "Não é raro que uma negligência ou leve imprudência acabe por produzir dano de extensão desproporcional à culpa do agente. (...) O CC permite, em casos semelhantes, que o juiz reduza eqüitativamente o montante da indenização de modo a conformá-la à intensidade da negligência ou imprudência do ofensor".

${ }^{39}$ STOCO, Rui. Op. cit., p. 140/141.
} 
À análise exclusiva deste dispositivo legal inédito, o parágrafo único do artigo 944 do Código Civil de 2002, objeto central deste estudo, dedicar-se-á, em sua integralidade, o capítulo 3, infra. Antes de ingressar neste mérito, contudo, tomou-se a preocupação de contextualizar o preceito normativo, situando-o, bem como o próprio sistema de responsabilidade civil pátrio, a partir da principiologia contida na tábua axiológica constitucional, dentro da lógica sistemática do ordenamento jurídico, primando-se, assim, pela leitura do mesmo em uma perspectiva de direito civil constitucional. Propõe-se a este dimensionamento o capítulo 2, a seguir. 


\section{Capítulo 2 - A axiologia constitucional e a responsabilidade civil}

\section{1 - A constitucionalização do direito privado}

$\mathrm{O}$ direito do século XIX e de primórdios do século XX, também conhecido como a Era das Grandes Codificações, tinha como característica a forte valorização da Summa Divisio, marcada separação entre os ramos do direito público e privado, duas esferas jurídicas notoriamente distintas e alheias uma à outra ${ }^{40}$. Assim, a Constituição era a carta de proteção das liberdades individuais burguesas do cidadão frente ao Estado, enquanto o Código Civil era o diploma que regulamentava os aspectos da vida particular dos sujeitos, do nascimento à morte. O que concernia ao direito privado era questão dos particulares, homens livres e autônomos, plenamente capazes de gerir, individualmente, seus interesses pessoais ${ }^{41}$.

Tal perspectiva vigeu por cerca de um sesquicentenário, até lhe começar a faltar o fôlego para acompanhar o célere ritmo de transformações que se perfizeram, ao decorrer do século $\mathrm{XX}^{42}$, em todas as ordens: econômica,

\footnotetext{
${ }^{40}$ MORAES, Maria Celina Bodin de. Constituição e Direito Civil: tendências. In: Revista dos Tribunais, vol. 89, n. ${ }^{\circ}$ 779, set 2000. p. 48: "A exigência de estabilidade, ou de previsibilidade, quanto aos comportamentos individuais passou a ser o pressuposto intrínseco das relações jurídicas na medida em que a burguesia francesa, vitoriosa da Grande Revolução, se tornou a nova classe dirigente, portadora da tábua de valores na qual toda a sociedade foi chamada a reconhecer-se. (...) Neste ambiente, como é fácil perceber, as relações do direito privado com o direito público estão claramente pré-definidas. $\mathrm{O}$ direito privado coincide com o âmbito dos direitos naturais e inatos dos indivíduos, enquanto o direito público é o emanado pelo Estado, dirigido a finalidades de interesse geral. As duas esferas, aqui, são praticamente impermeáveis".

${ }^{41}$ SARMENTO, Daniel. A trajetória da dicotomia público/privado. In: Revista Trimestral de Direito Civil, vol. 22, abr/jun 2005. p. 244/245: "Durante o Estado Liberal, o Código Civil desempenhou, nos países de tradição jurídica romano-germânica, o papel de uma espécie de constituição da sociedade. Naturalmente, os códigos exprimiam os valores mais caros à burguesia, tendo como pilares fundamentais a proteção da propriedade e a liberdade de contratar. Tarefa muito mais modesta cabia às constituições da época, seja pela limitação do seu objeto - não tratavam de relações privadas - seja pela sua reduzida eficácia jurídica, decorrente da visão legicentrista então prevalecente e da carência de instrumentos de jurisdição constitucional que permitissem sua efetivação".

${ }^{42}$ Quanto às transformações econômicas decorridas nesta época e suas implicações jurídicas, cumpre evocar a obra de TEPEDINO, Gustavo. O Código Civil, os chamados microssistemas e a Constituição: premissas para uma reforma legislativa. In: TEPEDINO, Gustavo (Coord.). Problemas de Direito Civil-Constitucional. Rio de Janeiro: Renovar, 2000. p. 03: "O entendimento ora criticado mostra-se, no entanto, bastante coerente com a lógica do individualismo oitocentista, sendo indiscutível o papel
} 
político-social, cultural e, inclusive, tecnológico-científica. Hoje, no século XXI, é uma perspectiva que frontalmente se ataca ${ }^{43}$. A detecção de situações em que há constante vulnerabilidade por parte de uma das partes contratantes, como nas relações de trabalho e de consumo, aliada à necessidade de adequada regulamentação dos mais diversos aspectos da vida contemporânea, cada vez mais fragmentada e polivalente, contribuiu para a edição de variados e específicos diplomas legislativos. O Código Civil fracassou como grande diploma legislativo apto a exercer a regulamentação efetiva de todos os

predominante que o Código Civil desempenhava como referência normativa exclusiva no âmbito das relações de direito privado. Tal quadro começa a se redefinir, gradativamente, na Europa já desde o início do Século XX, e no Brasil depois da década de 30, com a maciça intervenção do Estado na economia e com o processo, daí decorrente, de restrição à autonomia privada, ao qual se associa o fenômeno conhecido como dirigismo contratual". Em referência às transformações político-sociais do pós-guerra, destaquem-se as palavras de MORAES, Maria Celina Bodin de. Constituição e Direito Civil: tendências, p. 51/52: "Foi o século XX um século de importantes transformações na esfera jurídica, sobretudo no que tange à defesa da pessoa humana. (...) $\mathrm{O}$ século $\mathrm{XX}$ foi profundamente marcado por duas grandes guerras, pelos horrores efetivamente praticados pelo Estado constituído, especialmente durante o Nazismo. Sua política de racismo, destruição e morte, assegurada por lei, consentiu que fossem ultrapassados limites até então intransitados, provocando, como reação, a necessidade de concreta efetivação dos direitos humanos, subjazendo, ex novo, a idéia de que o direito ou é humano ou não é direito".

${ }^{43}$ Precisas, neste sentido, as palavras de LOTUFO, Renan. Da oportunidade da Codificação Civil e a Constituição. In: SARLET, Ingo Wolfgang (Org.). O Novo Código Civil e a Constituição. Porto Alegre: Livraria do Advogado, 2003. p. 18: "O Código [Civil] Francês, que deveria refletir os princípios da Revolução (Liberdade, Fraternidade e Igualdade), focaliza dois outros valores fundamentais: propriedade e contrato. Admite que a propriedade deve ser para todos e que deve existir liberdade contratual para todos. Essa liberdade é entendida como algo inato a todo ser humano, sendo que todo o ser humano é livre para contratar como e com quem quiser. Sabemos que essa estrutura de Código vai ser extremamente criticada no curso do tempo, pois é exatamente essa liberdade dada ao contratante que levou o fraco a ser submetido ao forte" (grifos no original). Semelhantes críticas ao velho modelo civilista, patrimonialista e individualista, poderiam ser evocadas para ilustrar o novo posicionamento da atual doutrina privatista pátria. Por seu caráter inaugural, deu-se preferência à obra que introduziu a doutrina do Direito Civil Constitucional ao Brasil, na voz de sua fundadora, MORAES, Maria Celina Bodin de. A Caminho de Um Direito Civil Constitucional. In: Revista de Direito Civil, Imobiliário, Agrário e Empresarial, vol. 17, n. ${ }^{\circ}$ 65, jul/set 1993. p. 22: "O direito civil foi identificado, a partir [da edição do Código Napoleônico de 1804], com o próprio Código Civil, que regulava as relações entre as pessoas privadas, seu estado, sua capacidade, sua família e, principalmente, sua propriedade, consagrando-se como o reino da liberdade individual. (...) Neste universo jurídico, as relações do direito público com o direito privado apresentam-se bem definidas. $\mathrm{O}$ direito privado insere-se no âmbito dos direitos naturais e inatos dos indivíduos. O direito público é aquele emanado pelo Estado para a tutela de interesses gerais. As duas esferas são quase impermeáveis (...). Nada mais diverso da concepção moderna: irreconhecível seria para os interpretes du Code a nova feição do direito civil (...). O direito civil viu modificadas as suas funções e não pode mais ser estimado segundo moldes do direito individualista dos séculos anteriores". 
aspectos da vida privada, bem como se ultrapassou a crença liberalista na suficiência da autonomia humana para resguardar seus próprios interesses ${ }^{44}$.

A miríade de normas que abunda e se faz necessária no atual cenário legislativo contemporâneo, em que cada diploma é decorrente de interesses e de preocupações políticas distintas, mais se assemelha a um emaranhado disforme que a um sistema integrado e harmônico. A conjuntura jurídica, com o colapso do sistema das grandes codificações, encontra-se em um estado de potência caótica: há uma infinidade indistinta de princípios e normas aptos a regular os mais variados aspectos da vida em sociedade, mas falta um elemento central capaz de dar àquela imensidão desordenada um sentido inteligível ${ }^{45}$. Ante este caos, a doutrina elegeu a Constituição, com fulcro em sua superioridade

\footnotetext{
44 TEPEDINO, Gustavo. O Velho Projeto de um Revelho Código Civil. In: TEPEDINO, Gustavo Temas de Direito Civil. Tomo I. $3^{\text {a }}$ Ed. Rio de Janeiro: Renovar, 2004., p. 499/500: "Vale dizer, uma codificação não surge por acaso. Expressa momento de unificação política e ideológica de um povo, fazendo prevalecer o conjunto de regras que a sintetiza. Assim foi no século XIX, após a Revolução Francesa, assim se deu na Europa do pós-guerra, com a derrubada dos governos totalitários. Tais circunstâncias históricas não mais existem: deram lugar a cenário inteiramente diverso, pluralista e multifacetado, onde grupos políticos emergentes manifestam-se através de robusto conjunto de leis especiais, que regula de maneira setorial a atividade privada e parece insuscetível de unificação no plano das leis ordinárias. Basta pensar no Estatuto da Criança e do Adolescente, no Código de Defesa do Consumidor, e na Lei das Locações Prediais Urbanas, todos posteriores ao projeto [do Código Civil de 2002, que remonta à década de 1970]. Tais estatutos não se limitam a tratar de forma específica situações excepcionais ou especiais, veiculando, inclusive, normas interpretativas, de direito administrativo, penais e processuais".

${ }^{45}$ PERLINGIERI, Pietro. Perfis do Direito Civil: Introdução do Direito Civil Constitucional. $3^{\mathrm{a}}$ Ed. Rio de Janeiro: Renovar, 2007. p. 06: "Numerosas leis têm disciplinado, embora de modo fragmentado e por vezes incoerente, setores relevantes. O Código Civil certamente perdeu a centralidade de outrora". Em detalhes: TEPEDINO, Gustavo. O Código Civil, os chamados microssistemas e a Constituição, p. 05: "Surgiram, ao longo do tempo, numerosos estatutos (...), bastando indicar, a título de exemplo, as sucessivas leis de locação predial urbana, o Código de Defesa do Consumidor, o Estatuto da Criança e do Adolescente. Esse longo percurso histórico, cujo itinerário não se poderia aqui palmilhar, caracteriza o que se convencionou chamar de processo de descodificação do direito civil, com o deslocamento do centro de gravidade do direito privado, do Código Civil, antes um corpo legislativo monolítico, por isso mesmo chamado de monossistema, para uma realidade fragmentada pela pluralidade de estatutos autônomos" (grifos no original). No mesmo sentido, a avaliação de MORAES, Maria Celina Bodin de. O Princípio da Dignidade Humana. In: MORAES, Maria Celina Bodin de. (Coord.). Princípios do Direito Civil Contemporâneo. Rio de Janeiro: Renovar, 2006. p. 03: "[A eleição da cláusula geral de tutela da dignidade humana como fio condutor do ordenamento jurídico] representava, com efeito, para os que se dedicavam ao estudo do direito das relações privadas, um passo decisivo, imprescindível, já que estava por se estabilizar o entendimento da fragmentação da disciplina, caotizada num emaranhado de microssistemas, ignorados tanto a unidade do ordenamento jurídico como seus princípios jurídicos gerais que, porém, desde há muito, não mais se podiam encontrar no Código respectivo".
} 
hierárquica, bem como na consolidação e síntese, em sua tábua axiológica, dos valores indispensáveis à própria interpretação e aplicação do direito pátrio, como fio condutor do ordenamento, instrumento capaz de operar a separação do tecido legislativo caótico, de modo que se torne inteligível, ao mesmo passo em que o conforma a uma principiologia uniforme que a seus componentes é superior, permitindo, assim, que mantenham uma relação harmônica, equilibrada, entre si e com a própria Constituição ${ }^{46}$.

O direito civil não é estranho a este processo. Ele também precisa conformar-se à axiologia constitucional. A Summa Divisio, antes hegemônica, hoje desprestigiada ${ }^{47}$, não tem o condão de afastar a influência da Carta Magna, fenômeno cunhado de "despatrimonialização do direito privado" "constitucionalização do direito civil"49.

\footnotetext{
${ }^{46}$ BARROSO, Luís Roberto. Fundamentos Teóricos e Filosóficos do Novo Direito Constitucional Brasileiro (Pós-modernidade, teoria crítica e pós-positivismo). In: A Nova Interpretação Constitucional: ponderação, direitos fundamentais e relações privadas. BARROSO, Luís Roberto (Org.) Rio de Janeiro: Renovar, 2003. p. 29/30: "Os princípios constitucionais, portanto, explícitos ou não, passam a ser a síntese dos valores abrigados no ordenamento jurídico. Eles espelham a ideologia da sociedade, seus postulados básicos, seus fins. Os princípios dão unidade e harmonia ao sistema, integrando suas diferentes partes e atenuando tensões normativas. De parte isso, servem de guias para o intérprete, cuja atuação deve pautar-se pela identificação do princípio maior que rege o tema apreciado, descendo do mais genérico ao mais específico, até chegar à formulação da regra concreta que vai reger a espécie."

7 Neste sentido, claras as palavras de MATTIETTO, Leonardo. O Direito Civil Constitucional e a Nova Teoria dos Contratos. In: TEPEDINO, Gustavo (Coord.). Problemas de Direito CivilConstitucional. Rio de Janeiro: renovar, 2000. p. 166: "Acolhida a tese de unidade do ordenamento jurídico, e bem assim da superioridade dos valores e princípios insculpidos na Constituição, cujo alcance se projeta no sistema jurídico como um todo, conduz à necessidade de abandonar a separação do direito em público e privado, posta pela doutrina tradicional. Não pode ser aceito o esquema que separa Estado e sociedade civil e concebe, de um lado, a Constituição como lei do Estado e, de outro, o direito privado como ordenamento da sociedade civil e que vê certas normas constitucionais como intromissões em um setor estranho, reservado aos particulares. (...) Ao contrário, é necessário trazer a lume o valor político das normas de direito privado e definir as suas funções em relação ao sistema sócio-político-econômico". Propondo a releitura desta dicotomia, SARMENTO, Daniel. Op. cit., p. 253: "A clivagem público/privado representa um esquema demasiadamente singelo para explicar o cenário atual, em que há múltiplos espaços da vida humana, pautados por lógicas diversas. Tais espaços, na verdade, não são separados de modo tão rígido e esquemático, penetrando-se frequientemente. Sem embargo, na nossa opinião, a idéia de separação entre os espaços público e privado, apesar da sua simplicidade, mantém ainda grande importância no cenário contemporâneo. Mas é bom que se diga que tal dicotomia não se confunde com àquela outra clivagem anteriormente abordada entre Direito Público e Privado, hoje em franca decadência".

${ }^{48}$ TEPEDINO, Gustavo. O Velho Projeto de um Revelho Código Civil, p. 500.

${ }^{49}$ MORAES, Maria Celina Bodin de. Apresentação. In: Princípios do Direito Civil Contemporâneo. Rio de Janeiro: Renovar, 2006, p. IX.
} 
É inafastável a necessidade de se lançar sobre a axiologia constitucional. Negar-se a fazê-lo implicaria na insistente reedição de um modelo jurídicointerpretativo do direito privado que acredita na auto-suficiência do diploma civilista, reconhecendo o Código como um monumento legislativo isolado e pleno, capaz de informar satisfatoriamente, por si só, os interesses privados da sociedade; e que trouxe resultados tortuosos e pouco profícuos. Opta-se, ao contrário, por perseguir um novo viés, buscar uma nova metodologia, a do direito civil constitucional, cujo ponto de partida é, justamente, a axiologia da Carta Maior, capaz de trazer nova sistematicidade ao ordenamento fragmentado em diversos diplomas e microssistemas.

\section{2 - Implicações da axiologia constitucional à responsabilidade civil}

$\mathrm{O}$ sistema de responsabilidade civil não fica alheio a este fenômeno. $\mathrm{Na}$ medida em que toda a dogmática privatista condiciona-se à principiologia constitucional, também este ramo do direito sofre alterações consideráveis em sua sistemática ${ }^{50}$.

Adequar o ordenamento à axiologia constitucional implica reconhecer, nos termos do artigo $1^{\circ}$, III, CRFB/88, a eleição da dignidade humana como fundamento da República, a ela se reportando como alicerce para construção da dogmática jurídica de inferior hierarquia ${ }^{51}$. O primado da dignidade humana

\footnotetext{
${ }^{50}$ MORAES, Maria Celina Bodin de. A constitucionalização do direito civil e seus efeitos sobre a

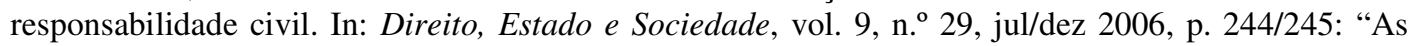
profundas transformações ocorridas na responsabilidade civil, ramo do direito civil que apresenta atualmente grandes desafios aos juristas, devem ser enfrentadas a partir da perspectiva da aplicação direta e imediata das normas constitucionais. De fato, somente a perspectiva constitucionalizada é capaz de oferecer respostas às complexas indagações presentes no direito dos danos contemporâneo".

51 CASTRO, Carlos Roberto Siqueira. Dignidade da pessoa humana: o princípio dos princípios constitucionais. In: GALDINO, Flavio e SARMENTO, Daniel (Orgs.). Direitos Fundamentais: Estudos em homenagem ao Professor Ricardo Lôbo Torres. p. 160: "o postulado da dignidade da pessoa humana em boa hora ingressou no direito positivo brasileiro, desde logo com a estatura inexcedível de norma de princípio constitucional, alçada em fundamento do Estado brasileiro (Constituição Federal - art. $1^{\circ}$, III), o que vale dizer em pressuposto axiológico da organização política nacional. Essa hierarquia juspositiva por certo faz resultar conseqüências extremas e inexoráveis, uma vez que irradia para o plano da legalidade infraconstitucional um padrão de interpretação e de execução normativa, que é de observância compulsória, e que deve ser consentâneo com a máxima efetividade da cláusula supralegal de dignificação do homem. Há de ocorrer, de conseguinte, a
} 
imprime ao jurista a necessidade de revisar os clássicos institutos jurídicos ${ }^{52}$, condicionando a sua aplicabilidade ao cumprimento deste preceito maior, que reconhece o valor intrínseco da espécie humana, apreciando o sujeito como um fim em si, digno de ocupar o cerne do ordenamento, como matriz axiológica ${ }^{53}$, instituindo, assim, verdadeira cláusula geral de tutela da pessoa.

Conseqüentemente, em razão da ascendência da cláusula geral de tutela da dignidade humana, as situações jurídicas existenciais necessariamente terão preponderância quando contrapostas às relações patrimoniais ${ }^{54}$. Ao lidar com o sistema de responsabilidade civil, o jurista deve dispensar maiores cuidados ao realizar a imprescindível reavaliação dos institutos a ele inerentes, pois se trata de uma dimensão jurídica em que imperativos existenciais e patrimoniais coexistem com maior proximidade.

Paralelamente, a adoção de um princípio de solidariedade social, nos termos do artigo $3^{\circ}$, I, CRFB/88, que elege o paradigma solidarista como um

constitucionalização, ou seja, a interpretação conforme a constituição, de todas as regras de direito que intercedam com as condições existenciais reputadas indispensáveis a uma vida digna" (grifos no original).

${ }^{52}$ FACHIN, Luiz Edson. O Futuro da Codificação e o Jurista do Amanhã; Idéias para um Debate. In: Revista da EMERJ, vol. 7, n. 26, abr/jun 2004. p. 117: "Fala-se, agora mais do que antes, numa principiologia axiológica de índole constitucional diante das crises e transformações que emergem das novas demandas calcadas em ideais como a plena cidadania, gerando mudanças nos papéis tradicionalmente cometidos aos institutos fundamentais do Direito Civil (...). A releitura de estatutos fundamentais do Direito Privado é útil e necessária para compreender a crise e a superação do sistema clássico".

53 MORAES, Maria Celina Bodin. O Princípio da Dignidade Humana, p. 15: "O princípio constitucional visa garantir o respeito e a proteção da dignidade humana não apenas no sentido de assegurar um tratamento humano e não degradante, e tampouco conduz ao mero oferecimento de garantias à integridade física do ser humano. Dado o caráter normativo dos princípios constitucionais, princípios que contêm os valores ético-jurídicos fornecidos pela democracia, isto vem a significar a completa transformação do direito civil, de um direito que não mais encontra nos valores individualistas de outrora o seu fundamento axiológico".

${ }^{54}$ MATTIETTO, Leonardo. O Direito Civil Constitucional e a Nova Teoria dos Contratos, p. 170: "A adjetivação do direito civil, dito 'constitucionalizado, socializado, despatrimonializado', ressalta o trabalho que incumbe ao intérprete de reler a legislação civil à luz da Constituição, de modo a privilegiar os valores não-patrimoniais, a dignidade da pessoa humana, os direitos sociais e a justiça distributiva, à qual devem se submeter a iniciativa econômica privada e as situações jurídicas patrimoniais" (grifos no original). Em assaz síntese, ver MORAES, Maria Celina Bodin de. A constitucionalização do direito civil e seus efeitos sobre a responsabilidade civil, p. 234: "De fato, a escolha do constituinte ao elevá-la [a dignidade humana] ao topo do ordenamento alterou radicalmente a estrutura tradicional do direito civil na medida em que determinou o predomínio necessário das situações jurídicas existenciais sobre as relações patrimoniais". 
dos objetivos fundamentais da República, também influencia diretamente o sistema de responsabilidade civil, na medida em que representa ruptura frontal com o velho regime do direito de danos ${ }^{55}$, nos moldes instituídos pelo Código Civil de 1916, marcadamente individualista e voluntarista, preocupado com questões de matiz estritamente patrimonial ${ }^{56}$. A tutela dos indivíduos, na responsabilidade civil de outrora, restringia-se ao resguardo de seu patrimônio, à necessidade de se atender pecuniariamente à ofensa material sofrida, não se considerando a figura do ofendido a partir de seu valor intrínseco, mas, por um viés estritamente patrimonialista, focando-se na importância de se reparar um decréscimo em sua riqueza. Tanto assim o era, que a disciplina originária da responsabilidade civil pátria sequer contemplava a hipótese de reparação de danos de natureza extrapatrimonial, considerando, até mesmo, a hipótese uma imoralidade $^{57}$. É evidente, portanto, como a preocupação do sistema calcava-se em diretrizes sumariamente patrimonialistas.

A ingerência dos preceitos constitucionais que reservam à dignidade humana e à solidariedade social especial distinção implica, necessariamente, a revisão desta lógica, dado que o direito privado, finalmente, submete-se a uma nova valoração, a partir de elementos sociais que o afetam indelevelmente, suprimindo os resquícios da ideologia liberal, outrora reinante, substituindo-a por um novo paradigma de justiça social e dignificação do homem ${ }^{58}$. Assim, a

\footnotetext{
${ }^{55}$ MORAES, Maria Celina Bodin de. O Princípio da Solidariedade. In: PEIXINHO, Manoel Messias et al. (Orgs.). Os Princípios da Constituição de 1988. Rio de Janeiro: Lúmen Júris, 2001. p. 181: "De todos estes campos do direito civil, contudo, aquele em que mais claramente se percebe o notável incremento das exigências da solidariedade é o da responsabilidade civil. A propagação da responsabilidade objetiva no século XX, através da adoção da teoria do risco, comprova a decadência das concepções do individualismo jurídico para regular os problemas sociais".

56 TEPEDINO, Gustavo. O Velho Projeto de um Revelho Código Civil, p. 500.

${ }^{57}$ FILHO, Sergio Cavalieri. Op. cit., p. 95: "Numa primeira fase, negava-se ressarcibilidade ao dano moral, sob fundamento de ser ele inestimável. Chegava-se, mesmo, ao extremo de considerar imoral estabelecer um preço para a dor".

${ }^{58}$ BITTAR, Carlos Alberto e FILHO, Carlos Alberto Bittar. A constituição de 1988 e o direito civil: os novos princípios fundamentais para o relacionamento privado. In: BITTAR, Carlos Alberto e FILHO, Carlos Alberto Bittar. Direito Civil Constitucional. $3^{\mathrm{a}}$ Ed. São Paulo: Revista dos Tribunais, 2003. p. 27: "O destaque dos elementos sociais impregnará o direito privado de conotações próprias, eliminando os resquícios ainda existentes do individualismo e do formalismo jurídico, para submeter o Estado
} 
dimensão existencial na responsabilidade civil ganha maior relevância. É hoje inadmissível sua sistematização em torno de determinações dogmáticas de caráter conspicuamente patrimonial.

Primordialmente, tal aprofundamento da grandeza existencial se traduz, no deslocamento do eixo gravitacional do sistema de responsabilidade civil da figura do ofensor para a do ofendido 59 .

Se, no passado, a responsabilidade civil procurava deflagrar condutas desviantes, valendo do instituto da culpa como elemento de filtragem do nexo de imputação, hoje ela perdeu tal função moralizadora. O desenvolvimento social e, sobretudo, tecnológico, a partir da Revolução Industrial do século XIX, mas principalmente no curso do século XX, permitiu a proliferação de atividades cuja própria natureza contribui para a possibilidade de ocorrência de danos, sem que, entretanto, seja possível realizar a estrita prova da culpa, nos termos do velho sistema de responsabilidade civil $^{60}$. Em verdade, sequer se concebe a prática de determinadas atividades sem que a elas esteja atrelada uma real possibilidade (rectius, probabilidade) de ocorrência de danos ${ }^{61}$. Em

brasileiro a uma ordem baseada em valores reais e atuais, em que a justiça social é fim último da norma, equilibrando-se mais os diferentes interesses por elas regidos".

59 MORAES, Maria Celina Bodin de. A constitucionalização do direito civil e seus efeitos sobre a responsabilidade civil, p. 238: "O princípio da proteção da pessoa humana, determinado constitucionalmente, gerou no sistema particular da responsabilidade civil, a sistemática extensão da tutela da pessoa da vítima, em detrimento do objetivo anterior de punição do responsável"; e ainda FILHO, Sergio Cavalieri, Op. cit., p. 155: "A vítima do dano, e não mais o autor do ato ilícito, passa a ser o enfoque central da responsabilidade civil. Em outras palavras, a responsabilidade, antes centrada no sujeito responsável, volta-se para a vítima e a reparação do dano por ela sofrido".

${ }^{60}$ FILHO, Sergio Cavalieri, Op. cit., p. 143/144: "Costuma-se apontar, em apertada síntese, a revolução industrial do século [XIX], o progresso científico e a explosão demográfica que nele ocorreu como sendo os principais fatores que ensejaram nova concepção de responsabilidade civil. Com efeito, se o desenvolvimento do maquinismo fez surgir a indústria, mudando a base econômica do País, trouxe como consequiência os acidentes de trabalho. O progresso científico fez aparecer um sem-número de inventos, enchendo as ruas de veículos que, se, por um lado, facilitam a vida em sociedade, por outro, dão causa a um brutal número de acidentes (...). Logo os juristas perceberam que a teoria subjetiva não mais era suficiente para atender a essa transformação social ocorrida em nosso século; constataram que, se a vítima tivesse que provar a culpa do causador do dano, em numerosíssimos casos ficaria sem indenização, ao desamparo, dando causa a outros problemas sociais".

${ }^{61}$ MORAES, Maria Celina Bodin de. Danos à Pessoa Humana, p. 150: "Em nossa época - é voz corrente - há muitíssimas mais ocasiões de risco, de perigo, em decorrência, não só mas também, do acentuado desenvolvimento tecnológico; neste sentido, conclui-se ter havido um real incremento das possibilidades de causação de danos". 
síntese, o desenvolvimento social e tecnológico rumou no sentido de instituir uma realidade em que o risco de lesão é perene ${ }^{62}$.

Neste novo cenário, infrutíferos provaram-se os esforços no sentido de, valendo-se do sistema de responsabilidade civil, desestimular o dano, pois este se tornou um elemento esperado - ainda que indesejado - de grande parte das atividades humanas da sociedade moderna. Constatou-se, finalmente, após gradativos esforços no sentido de introduzir um novo nexo de imputação por meio da teoria do risco, a necessidade de se atribuir à responsabilidade civil novo papel. Sua função precípua e sua preocupação essencial não repousariam mais na eleição e filtragem das condutas às quais se imputa o dever de indenizar por meio da noção de ato ilícito, e sim na busca do ressarcimento completo da vítima pelo dano injusto, operando, assim, verdadeiro giro conceitual $^{63}$.

Neste novo cenário, marcadas tendências se acentuam, buscando, sobremaneira, meios para a satisfação integral do prejuízo, sofrido pela vítima $^{64}$, em conformidade ao princípio da dignidade humana, à preceituação

\footnotetext{
${ }^{62}$ Ibid. p. 325: "A propagação de responsabilidade objetiva no século XX, através da adoção da teoria do risco, confirma, sem dúvida, a incapacidade das concepções do individualismo jurídico (e, é claro, do liberalismo econômico) para regular os problemas sociais. A multiplicação de acidentes anônimos, que deixavam a vítima ao completo desamparo, fez com que, paulatinamente, a consciência coletiva se decidisse a atribuir deveres de responsabilidade, não apenas em razão de manifestação culposa ou dolosa, mas também em decorrência da atividade exercida (e dos benefícios dela extraídos), através das noções de risco-proveito e risco-criado."

${ }^{63}$ MORAES, Maria Celina Bodin de. O Princípio da Solidariedade, p. 181: “A responsabilidade civil (...) subverteu, assim, a antiga coerência do sistema, superando completamente, em diversos casos, o objetivo de identificação do culpado - o responsável - pela responsabilidade sem culpa, considerada por muitos como um verdadeiro compromisso com a solidariedade social". Id. A constitucionalização do direito civil e seus efeitos sobre a responsabilidade civil, p. 245: "Se a responsabilidade civil tradicional se baseava exclusivamente na tutela do direito de propriedade e dos demais direitos subjetivos patrimoniais, hoje a dignidade da pessoa humana, a solidariedade social, e a justiça distributiva influenciam profundamente toda sistemática do dever de ressarcir. A constitucionalização do direito dos danos impôs, como se viu, a releitura da própria função primordial da responsabilidade civil. O foco que tradicionalmente recaía sobre a pessoa do causador do dano, que por seu ato reprovável deveria ser punido, deslocou-se no sentido da tutela especial garantida à vítima do dano injusto, que merece ser reparada".

${ }^{64}$ SCHREIBER, Anderson. Op. cit., p. 56/57: "a erosão dos filtros da responsabilidade civil se explica, em larga medida, por uma sensibilidade crescente dos tribunais à necessidade de assegurar alguma reparação às vítimas de um dano. (...) o objetivo das cortes, na aplicação da responsabilidade civil, tem sido menos o de identificar um responsável que se vincule (pela sua culpa ou pela sua atividade) ao
} 
da cláusula geral de tutela da pessoa, e aos ditames do paradigma de solidariedade social ${ }^{65}$.

\section{3 - O princípio da reparação integral}

Naturalmente, na medida em que o próprio foco da responsabilidade civil, como relatado supra, migra da figura do ofensor para o ofendido, uma vez que a preocupação doutrinária primordial deixa de ser o ato ilícito e passa a ser o dano injusto, também cresce o debate em torno da eleição de critérios para o ressarcimento desta lesão injustamente perpetrada.

O dano injusto é, em verdade, o elemento central de todo o sistema, uma vez que, na sua ausência, não há que sequer se falar em responsabilidade civil $^{66}$. Portanto, o dano, entendido como a lesão a um bem juridicamente tutelado, seja de natureza patrimonial ou extrapatrimonial, configura-se não apenas como componente caracterizador do dever de indenizar, mas como seu próprio elemento determinante.

A questão da quantificação indenizatória, conseqüentemente, também recebe maior destaque, afinal, o sistema do direito de danos contemporâneo percorre a sua órbita ao redor da satisfação da vítima pela ofensa injustamente sofrida ${ }^{67}$.

\footnotetext{
dano, e mais o de assegurar, por qualquer meio disponível, a integral reparação dos prejuízos sofridos pela vítima".

${ }^{65}$ MORAES, Maria Celina Bodin de. A constitucionalização do direito civil e seus efeitos sobre a responsabilidade civil, p. 239: "Já a canônica finalidade de moralização da responsabilidade civil parece ter sido substituída com vantagens pela concepção que vislumbra no instituto a presença, e a conseqüente realização, de um dever geral de solidariedade, também hoje previsto constitucionalmente $\left(\mathrm{CF}\right.$, art. $\left.3^{\circ}, \mathrm{I}\right)$, que se encontra na base do aforismo multissecular do neminem laedere, isto é, da obrigação de comportar-se de modo a não lesar os interesses de outrem".

${ }^{66}$ FILHO, Sergio Cavalieri, Op. cit., p. 88/89: "Pode haver responsabilidade [civil] sem culpa, mas não pode haver responsabilidade [civil] sem dano. (...) Sem dano pode haver responsabilidade penal, mas não há responsabilidade civil. Indenização sem dano importaria enriquecimento ilícito; enriquecimento sem causa para quem a recebesse e pena para quem a pagasse, porquanto o objetivo da indenização, sabemos todos, é reparar o prejuízo sofrido pela vítima, reintegrá-la ao estado em que se encontrava antes da prática do ato ilícito. E, se a vítima não sofreu nenhum prejuízo, a toda evidência, não haverá o que ressarcir. Daí a afirmação, comum praticamente a todos os autores, de que o dano é não somente o fato constitutivo, mas, também, determinante do dever de indenizar".

67 MORAES, Maria Celina Bodin de. Danos à Pessoa Humana, p. 151: "O princípio maior da responsabilidade civil contemporânea estava presente: a vítima não pode ficar irressarcida”.
} 
Neste cenário, portanto, com inequívoca certeza se pode dizer que teve o clássico princípio da reparação integral (restitutio in integrum) reafirmada a sua relevância, pois a responsabilidade civil não mais está preocupada, mormente, com a identificação do autêntico perpetrador da ofensa danosa, mas com o estabelecimento de critérios que permitam, por meio de um liame jurídico, determinar em que circunstâncias e a que pessoas se deve atribuir o ônus da reparação do dano sofrido pela vítima, o qual, a priori ${ }^{68}$, deve ser restituído integralmente ${ }^{69}$.

A integralidade da reparação é uma determinação dogmática, essencial ao próprio conceito de indenização. O propósito da indenização, no sistema responsabilidade civil é devolver a vítima (rectius, seu patrimônio) ao estado em que se encontrava anteriormente ao evento danoso. O termo "indenização" - tornar indene, incólume -, por si só, já evidencia a finalidade do instituto, qual seja: a de recompor o dano da maneira mais completa possível ${ }^{70}$.

A normativa privatista brasileira contemporânea abraça o princípio da reparação integral, trazendo-o como princípio informador de disposição de lei expressa, no Código Civil pátrio, conforme consta na dicção do caput do artigo 944: “A indenização mede-se pela extensão do dano”. A lei é, enfim, explícita ao atrelar a quantificação da verba indenizatória à mensura das dimensões da ofensa. Ao fazê-lo, está preocupada em oferecer à vítima completo amparo, assegurando integral reparação do prejuízo injustamente sofrido ${ }^{71}$. Ao aplicar

\footnotetext{
${ }^{68}$ Faz-se tal ressalva, naturalmente, em virtude de o principal objeto de estudo desta monografia, o dispositivo contido no parágrafo único do artigo 944 do Código Civil, representar uma exceção ao princípio de que ora se trata, conforme se verá em detalhes no capítulo 3, a seguir.

${ }^{69}$ MORAES, Maria Celina Bodin de. Danos à Pessoa Humana, p. 154: "o problema da responsabilidade civil não consiste na investigação ou na descoberta do 'verdadeiro' autor do fato danoso. Ele diz respeito, apenas, 'à fixação do critério graças ao qual se pode substituir a atribuição automática do dano por um critério jurídico'; isto é, trata-se de estabelecer quem, em que condições e no âmbito de que limites deve suportar o dano".

${ }^{70}$ FILHO, Sérgio Cavalieri, Op. cit., p. 125: "É o velho princípio da restitutio in integrum, a própria razão de ser da indenização. Busca-se com ela recolocar a vítima, tanto quanto possível, na situação anterior à lesão. A indenização é proporcional ao dano sofrido pela vítima, já que o objetivo da indenização - tornar indene - é reparar o dano o mais completamente possível".

71 TEPEDINO, Gustavo et al. Código Civil interpretado conforme a Constituição da República. vol. II. Rio de Janeiro: Renovar, 2006: p. 859: “Tais razões [solidaristas] inspiraram o legislador de 2002,
} 
este dispositivo, é preciso atentar, contudo, à natureza da lesão cuja medida se pretende aferir. O dano, como referido supra, pode ter natureza patrimonial ou extrapatrimonial, e há substancial diferença no tratamento jurídico de sua reparação, em razão de tal distinção ${ }^{72}$.

O dano de natureza patrimonial, como o nome sugere, é toda lesão que atinja os bens jurídicos que compõem o acervo patrimonial da vítima ${ }^{73}$, devendo este ser compreendido como o complexo de relações jurídicas economicamente mensuráveis de uma $\operatorname{pessoa~}^{74}$. Identifica-se sua ocorrência pela efetiva prova de concreto prejuízo material sofrido pela vítima, uma operação praticamente matemática, em que se demonstra um decréscimo financeiro fático causado pela ofensa $\operatorname{suportada}^{75}$. O dano patrimonial é, portanto, passível de estimativa monetária, e sua reparação se pode dar pela recomposição do próprio bem tolhido, ou por uma indenização pecuniária do equivalente em moeda corrente ${ }^{76}$.

O dano extrapatrimonial, por sua vez, é toda lesão que, independente de causar simultânea repercussão na esfera patrimonial da vítima ${ }^{77}$, a atinja em

que fez constar do art. 944 do CC a regra segundo a qual a indenização se mede pela extensão do dano. A nova codificação vem, assim, consagrar a idéia de que doutrina e jurisprudência brasileiras já imputavam à responsabilidade civil por meio do chamado princípio da reparação integral do dano. A idéia consiste em atribuir ampla proteção à vítima, empregando-se todos os esforços para fazê-la retornar ao status quo anterior ao prejuízo".

72 Doutrinariamente, distinções entre os danos patrimoniais e extrapatrimoniais podem ser tracejadas a partir de inúmeros fatores: a natureza dos bens jurídicos lesados, os efeitos de tal lesão, a identificação da ocorrência de danos, os critérios para reparação dos mesmos, até a forma da sua liquidação. Restringindo-se ao que interessa estritamente a este trabalho, diretamente dirigir-se-á aos distintos critérios de reparação dos danos patrimonial e extrapatrimonial. Para uma visão sistemática da responsabilidade civil na perspectiva do direito civil constitucional, sobretudo no que tange aos danos morais, torna-se a referir à fundamental obra de MORAES, Maria Celina Bodin de. Danos à Pessoa Humana, p. 158 e seguintes.

${ }^{73}$ FILHO, Sérgio Cavalieri, Op. cit., p. 89.

${ }^{74}$ TEPEDINO, Gustavo et al. Código Civil Interpretado Conforme a Constituição da República. vol. I, p. 188/189.

${ }^{75}$ MORAES, Maria Celina Bodin de. Danos à Pessoa Humana, p. 158.

76 VARELA, João de Matos Antunes. Das Obrigações em Geral, p. 594/595: "Alude-se ao dano patrimonial ou material para abranger os prejuízos que, sendo susceptíveis de avaliação pecuniária, podem ser reparados ou indemnizados, senão directamente (mediante restauração natural ou reconstituição específica da situação anterior à lesão), pelo menos indirectamente (por meio de equivalente ou indemnização pecuniária)" (grifos no original).

${ }^{77}$ VENOSA, Sílvio de Salvo. Direito Civil. vol. II. Teoria Geral das Obrigações e Teoria Geral dos

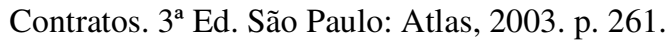


sua dimensão humana, alvejando seus direitos da personalidade, alheios ao patrimônio econômico, afeitos à sua dignidade inata ${ }^{78}$. A ocorrência do dano extrapatrimonial não se demonstra mediante prova. Ao contrário, sua existência decorre do próprio fato danoso. A repercussão da ofensa na estrutura moral da vítima deve ser detectada a partir da apreciação da própria conduta lesiva da qual deriva. Por esta razão refere-se ao dano extrapatrimonial como um dano in re ipsa ${ }^{79}$. Quanto ao seu ressarcimento, ele não pode ser, a rigor, indenizado, nem as verbas reparatórias podem ser quantificadas a partir da mensura de sua extensão, pois esta espécie é, por definição, incomensurável. Fala-se, apropriadamente, em compensação ${ }^{80}$ do dano extrapatrimonial e em estipulação de critérios para o arbitramento por parte do magistrado para a sua adequada quantificação ${ }^{81}$.

Discute-se o cabimento de possível caráter punitivo na satisfação do dano extrapatrimonial, aos moldes da doutrina estadunidense de punitive

\footnotetext{
${ }^{78}$ Neste sentido, LÔBO, Paulo Luiz Netto. Danos morais e direitos da personalidade. Disponível em http://jus2.uol.com.br/doutrina/texto.asp?id=4445. Acesso em 16 de outubro de 2007: "os direitos de personalidade oferecem um conjunto de situações definidas pelo sistema jurídico, inatas à pessoa, cuja lesão faz incidir diretamente a pretensão aos danos morais, de modo objetivo e controlável, sem qualquer necessidade de recurso à existência da dor ou do prejuízo". Originalmente, como dano extrapatrimonial era considerada toda lesão que causasse dor, sofrimento, angústia ao ofendido. Este velho conceito já se supera. Neste viés, precisas são as palavras de FILHO, Sérgio Cavalieri. Op. cit., p. 98: "Dor, vexame, sofrimento e humilhação são consequiência, e não causa. Assim como a febre é o efeito de uma agressão orgânica, dor, vexame e sofrimento só poderão ser considerados dano moral quando tiverem por causa uma agressão à dignidade de alguém". Por uma visão mais ampla do conceito de dano extrapatrimonial, ver MORAES, Maria Celina Bodin de. Danos à Pessoa Humana, p. 183/184: “o dano moral não pode ser reduzido à 'lesão a um direito da personalidade', nem tampouco ao 'efeito extra-patrimonial da lesão a um direito subjetivo, patrimonial ou extrapatrimonial'. Tratarse-á sempre de violação da cláusula geral de tutela da pessoa humana, seja causando-lhe um prejuízo material, seja violando direito (extrapatrimonial) seu, seja, enfim, praticando, em relação à sua dignidade, qualquer 'mal evidente' ou 'perturbação', mesmo se ainda não reconhecido como parte de alguma categoria jurídica".

${ }^{79}$ FILHO, Sergio Cavalieri, Op. cit., p. 101.

${ }^{80}$ MORAES, Maria Celina Bodin de. Danos à Pessoa Humana, p. 145: "Aquele que sofre um dano moral deve ter direito a uma satisfação de cunho compensatório. Diz-se compensação, pois o dano moral não é propriamente indenizável; 'indenizar' é palavra que provém do latim 'in dene', que significa devolver (o patrimônio) ao estado anterior, ou seja, eliminar o prejuízo e suas consequiências - o que, evidentemente, não é possível no caso de uma lesão de ordem extrapatrimonial. Prefere-se, assim, dizer que o dano moral é compensável, embora o próprio texto constitucional, em seu artigo $5^{\circ}$, $\mathrm{X}$, se refira à indenização do dano moral" (grifos no original).

${ }^{81}$ O tema será resgatado, e evidenciada sua correlação ao parágrafo único do artigo 944, no momento oportuno do capítulo seguinte.
} 
damages (expressão que comumente se traduz como "danos punitivos", porém mais se aproxima de "indenização punitiva").

Parte da doutrina, encabeçada por Maria Celina Bodin de Moraes e Gustavo Tepedino, é refratária a incorporação de tal atributo, defendendo que a responsabilidade civil brasileira, cumprindo sua finalidade típica, desconhece propósitos punitivos, estando estes afeitos às responsabilidades penal e administrativa. Na perspectiva civil constitucional, o giro conceitual operado no ordenamento e, conseqüentemente, no sistema de responsabilidade civil, trazendo seu foco para a figura da vítima, e não do ofensor, contribuiria ainda mais para o afastamento de tal possibilidade, pois a ótica solidarista diz respeito a ver tutelada a dignidade da pessoa lesada, não em identificar um culpado e lhe impingir medidas de natureza punitiva ${ }^{82}$.

A doutrina reversa, encabeçada por outros célebres, como José Carlos Moreira Alves e Caio Mario Pereira da Silva, defende a existência, dentro do vasto espectro humano, duma dimensão que anseia por punição. Há um espírito vingativo que é tão inato à condição humana, quanto a dignidade que se tutela constitucionalmente. $\mathrm{O}$ dano extrapatrimonial somente atingiria o seu propósito compensatório, satisfazendo cabalmente a vítima, apenas se também saciasse este seu sentimento retaliativo ${ }^{83}$.

Ainda mais, contribuiria para a educação e moralização do meio social, pois se atribuiria um gravame excepcional aos excessivamente relapsos e aos vis, respeitando, assim, a noção de justiça atributiva, que não permite que o mesmo tratamento seja dispensado àquele que, vítima de um momento de infeliz fraqueza, provoca danos que não desejava ocasionar, e àquele, maucaráter, que deliberadamente, ou desprovido da mais ordinária diligência, toma atitude que lesa outrem.

\footnotetext{
${ }^{82}$ Para uma síntese da posição refratária ao caráter punitivo genérico dos danos extrapatrimoniais, ver MORAES, Maria Celina Bodin de. Punitive Damages em sistemas civilistas: problemas e perspectivas. In: Revista Trimestral de Direito Civil, vol. 18, abr/jun 2004, p. 45 - 78.

${ }^{83}$ SILVA, Caio Mario Pereira da. Responsabilidade Civil, p. 315 e ss.
} 
Embora ambas as espécies de dano sejam informadas pelo princípio da reparação integral, percebe-se, claramente, que há uma distinção fundamental entre elas no que tange aos seus critérios de reparação. Esta diferenciação tem provocado debates na doutrina e será retomada, no momento oportuno, quando se discutir o alcance do parágrafo único do artigo 944, no capítulo que segue. 


\section{Capítulo 3 - O Código Civil de 2002 e a inovação trazida pelo parágrafo único do artigo 944}

\section{1 - A inteligência do dispositivo}

O parágrafo único do artigo 944 do Código Civil de 2002, sem qualquer correspondência a algum dispositivo legal que o preceda, traz a inovadora possibilidade de o magistrado, ao apreciar o caso concreto, diante de situação em que ocorra excessiva desproporção entre a gravidade da culpa do agente e a dimensão do dano ocasionado, reduzir o valor do montante indenizatório ${ }^{84}$. É o caso, por exemplo, de uma torneira mal fechada que resulta em uma custosa infiltração, ou de uma bagana de cigarro que se esquece acesa por um pequeno descuido e provoca um incêndio extenso. Em hipóteses como estas, poderia o juiz intervir, justificadamente, de modo a não onerar em demasia o ofensor.

Propõe-se o dispositivo, ao fazê-lo, a redistribuir o ônus trazido pelo evento danoso entre agente e vítima, confiando ao prudente e fundamentado discernimento do juiz a faculdade de reconhecer em quais dimensões fáticas se dariam danos excessivamente extensos para serem suportados exclusivamente por eventual ofensor que obrasse com abreviada culpa ${ }^{85}$.

O espírito que norteia o dispositivo é o princípio da solidariedade social, um dos novos elementos de balizamento do sistema de responsabilidade civil contemporâneo $^{86}$. Inicialmente, este preceito contribuiu para a objetivação da responsabilidade civil, direcionando os esforços de redistribuição social dos

\footnotetext{
${ }^{84}$ Diz o artigo 944, parágrafo único, do Código Civil de 2002: "Se houver excessiva desproporção entre a gravidade da culpa e o dano, poderá o juiz reduzir, eqüitativamente, a indenização".

${ }^{85}$ Em comentário ao dispositivo de TEPEDINO, Gustavo et al. Código Civil Interpretado Conforme a Constituição da República. vol. II, é criticada a lógica da adoção da culpa como critério para operar tal balanceamento do ônus reparatório, conforme p. 860: "o parágrafo único do art. 944 perde um pouco de seu sentido, já que, se não é justo onerar excessivamente o agente que agiu com culpa leve, menos justo ainda seria onerar a vítima, que não agiu com culpa alguma".

${ }_{86}$ MORAES, Maria Celina Bodin de. A constitucionalização do direito civil e seus efeitos sobre a responsabilidade civil, p. 245: "Se a responsabilidade tradicional se baseava exclusivamente na tutela do direito de propriedade e dos demais direitos subjetivos patrimoniais, hoje a dignidade humana, a solidariedade social e a justiça distributiva influenciam profundamente toda a sistemática do dever de ressarcir".
} 
riscos, tendo em mente a necessidade de se resguardar, ao máximo, a integridade (patrimonial e psicofísica) do indivíduo diante da exponencial proliferação da possibilidade de dano ${ }^{87}$. Atualmente, o princípio insiste nesta mesma dinâmica de apreciação e distribuição dos ônus trazidos pelo evento danoso. O dispositivo não pretende ressuscitar o velho paradigma moralizador da responsabilidade civil, buscando premiar a diligência, a partir da graduação do comportamento culposo, e sim aperfeiçoar o novo paradigma solidarista, que deve priorizar a vítima, mas jamais proscrever a figura do agente, uma vez que também esta integra a trama social e é merecedora de tutela jurídica. Rompe-se, assim, com a velha questão de justiça comutativa, que resumia a responsabilidade civil a uma disputa entre quem deveria suportar socialmente o ônus do dano, ora oscilando para a figura do autor do ato ilícito, ora para a figura do lesado ${ }^{88}$. Concretiza-se posição harmonizadora em que, a critério da ponderada (rectius, justificada) discrição do juiz, reparte-se tal ônus.

A opção legislativa, afinal, parece ter nascido da incorporação de antiga crítica feita ao sistema, de que, por vezes, ao invés de obrigar o agente a reparar extenso dano provocado por conduta levemente culposa, sentir-se-ia tentado o magistrado a frontalmente negar a própria ocorrência da culpa, de modo a livrar o ofensor da desproporcional obrigação de indenizar ${ }^{89}$. Contido

\footnotetext{
${ }^{87}$ Ibid. p. 252: "Em decorrência do princípio constitucional da solidariedade social, pois, distribuem-se as perdas e estende-se o mais amplamente possível as garantias à integridade psicofísica e material de cada pessoa humana. Esta é a razão justificativa, a um só tempo ética e jurídica, do deslocamento dos custos do dano da vítima para o responsável pela atividade".

${ }^{88}$ VARELA, João de Matos Antunes. Das Obrigações em Geral, p. 572: "O que está em causa, no domínio da responsabilidade civil, é uma questão elementar de justiça comutativa, que se resume em saber quem é mais justo que suporte o dano, se o titular da coisa ou do direito lesado, se o autor do facto ilícito" (grifos no original).

89 ALVIM, Agostinho apud DIREITO, Carlos Alberto Menezes e FILHO, Sérgio Cavalieri. Da responsabilidade civil, das preferências e privilégios creditórios: arts. 927 a 965. In: TEIXEIRA, Sálvio de Figueiredo (Coord). Comentários ao Novo Código Civil. vol. XIII. Rio de Janeiro: Renovar, 2004. p. 333: "Sucede, às vezes, que, por culpa leve, sem esquecer uma dose de fatalidade, vê-se alguém obrigado a reparar prejuízos de vastas proporções. O juiz poderia sentir-se inclinado a negar a culpa, para evitar uma condenação que não comporta meio-termo". No mesmo sentido, GONÇALVES, Carlos Roberto. Responsabilidade Civil. 9a Ed. São Paulo: Saraiva, 2005. p. 490: “O montante da indenização nunca pode exceder o valor dos danos causados ao lesado. E, no vigente Código Civil, não deve ser menor que estes. Entretanto, a muitos tal solução pode não se revelar justa,
} 
no dispositivo, portanto, reside um ponto de equilíbrio entre o cuidado com a vítima e a necessidade do autor, acreditando-se no criterioso e arrazoado discernimento do magistrado para a operação desta inflexão.

Não se pode olvidar, entretanto, ao formular tal arbítrio, que a figura da vítima permanece como elemento central de toda a sistemática da obrigação de indenizar. O legislador, aliás, não foi leviano ao compor a norma, elegendo cuidadosamente o termo "reduzir", em observância à primazia do ofendido, o qual não deve restar irressarcido, e excluindo, sumariamente, a possibilidade de supressão do dever de reparar.

Trata-se, em síntese, de mero mecanismo de repartição de riscos sociais entre agressor e vítima ${ }^{90}$, operando, desta maneira, mais uma etapa no processo de transformação do sistema de responsabilidade civil pátrio, o qual, a partir do reconhecimento do princípio constitucional da solidariedade social como diretriz, assume papel de instrumento de controle e distribuição dos riscos apresentados pela vida em sociedade ${ }^{91}$.

\section{2 - A literalidade do dispositivo}

\subsection{1 - Gravidade da culpa}

Como referido supra ${ }^{92}$, a culpa em sentido estrito pode ser considerada em três graus - levíssima, leve e grave -, a partir do conceito normativo de culpa, a depender da variação objetivamente experimentada do parâmetro de comportamento socialmente esperado. O artigo 944 do Código Civil, em seu

\footnotetext{
em casos de culpa extremamente leve. Melhor seria que a indenização pudesse ser fixada em montante inferior ao dano, em certos casos. É a solução adotada no art. 944 do Código Civil brasileiro".

90 TEPEDINO, Gustavo et al. Código Civil Interpretado Conforme a Constituição da República. vol. II, p. 861.

${ }^{91}$ MORAES, Maria Celina Bodin de. A constitucionalização do direito civil e seus efeitos sobre a responsabilidade civil, p. 253: "É sob esta benigna influência [dos preceitos constitucionais, entre os quais a solidariedade social] que se deve analisar o movimento de rotação completo da finalidade da responsabilidade civil que se observou no último quartel do séc. XX, conquistando o lugar central a idéia de que a vítima não deve permanecer irressarcida e funcionando o sistema da responsabilidade como um mecanismo de controle e distribuição dos riscos da vida em sociedade".
} 
parágrafo único, ao referir-se à "gravidade da culpa", revitalizou ${ }^{93}$ a discussão doutrinária acerca destes graus, debate considerado originariamente infrutífero, em função de sua irrelevância para a finalidade de caracterização do nexo de imputação 94 .

A recondução da gradação da culpa à pauta de discussão, operada pelo dispositivo legal, causou perplexidade na doutrina, que inicialmente acusou uma contradição entre os parâmetros oferecidos, quais sejam: a extensão do dano e a intensidade da culpa. O primeiro, logicamente, dispunha do segundo. Ou se reconhece a necessidade de mensurar o prejuízo causado e se o repara por completo, ou se nivela a obrigação de indenizar a partir da participação culposa, fixando-se os valores de ressarcimento num patamar mais alto em proporção à maior gravidade culposa da conduta ${ }^{95}$.

Pretendeu-se, inclusive, reinterpretar o dispositivo, sustentando alguns, que a norma em pauta, apesar de falar em "gravidade da culpa", reportar-se-ia, em verdade, à eficácia da contribuição causal ${ }^{96}$, traçando-se um paralelo com

\footnotetext{
${ }^{92}$ Ver capítulo 1, em específico, item 1.3.

${ }^{93}$ VENOSA, Silvio de Salvo. Direito Civil, vol. I. p. 595: "Na doutrina tradicional, tal distinção [entre os graus de culpa] é irrelevante, pois no sistema de 1916 o elemento fundamental é o prejuízo e não o grau de culpa, pois mesmo a culpa levíssima criará o dever de indenizar. Ultimamente, temos sentido uma reviravolta nesses paradigmas clássicos. (...) o grau de culpa passa a ter influência na fixação da indenização, o que, no passado, não era admitido".

94 VARELA, João de Matos Antunes. Das Obrigações em Geral, p. 567: "Uma vez apurada a culpa do agente, este é obrigado a indemnizar". E arremata, na p. 568: "Não se atende, para o efeito, às distinções de sabor escolástico que os autores costumavam estabelecer entre culpa lata (grave ou grosseira), culpa leve e culpa levíssima" (grifos no original). No mesmo sentido, PEREIRA, Caio Mario da Silva. Responsabilidade Civil, p. 71.

${ }^{95}$ MORAES, Maria Celina Bodin de. Danos à Pessoa Humana, p. 296/297: “A doutrina clássica, de fato, considerava que nenhuma relação deveria haver entre a amplitude dos danos e a gravidade da culpa. Nestes casos, então, e com absoluta independência do grau de culpa do agente, caberia sempre indenizar toda a extensão do dano, mesmo sendo a culpa levíssima causadora de dano gravíssimo. A escolha legislativa pela irrelevância do grau de culpa foi uma opção de ordem lógica. Uma alternativa excluía a outra, porque das duas, uma: ou bem se determina a indenização de todo o dano, e o grau da culpa não poderia ser levado em consideração, ou bem se media a conduta, permitindo a indenização menor do que seria necessário à reparação, em caso de culpa mais leve".

${ }^{96}$ CRUZ, Gisela Sampaio da. O Problema do Nexo Causal na Responsabilidade Civil. Rio de Janeiro: Renovar, 2005. p. 325: “A gravidade da culpa não serve, frise-se, como 'medida' da indenização, nem mesmo é, a nosso ver, adequada para determinar a distribuição do prejuízo entre os agentes coresponsáveis pelo dano. É o nexo causal o elemento que deve exercer essa função". E arremata, na p. 333: "A culpa, frise-se uma vez mais, não deve servir como medida da indenização. Este papel cabe, isto sim, ao nexo causal".
} 
similar escolha terminológica empreendida no dispositivo legal seguinte, o artigo 945 do Código Civil de 2002, que também faz expressa menção à gravidade da culpa ${ }^{97}$.

Sustenta-se, mormente, que não é a gravidade da culpa o parâmetro de distribuição do dever de indenizar, mas o nexo causal, pois, por vezes, embora não seja o usual, aquele que obra em culpa grave (ou mesmo dolo) provoca danos de pequena monta, ao passo que as culpas leve e levíssima podem levar à produção de danos exorbitantes. Critério mais justo adviria da apreciação do nexo de causalidade, ou melhor, da eficaz contribuição causal ao resultado lesivo, pois, desta forma, sempre se veria obrigado o agente a arcar com a indenização na exata proporção com que seu comportamento contribuiu para a ocorrência do efeito nocivo ${ }^{98}$. Ainda mais, ao se eleger a causalidade como baluarte do sistema, e não a gravidade da culpa, não haveria obstáculos à sua aplicação indistinta às responsabilidades subjetiva e objetiva ${ }^{99}$.

Embora se admita a crítica à terminologia legislativa, quando endereçada ao artigo 945 do Código Civil ${ }^{100}$, é forçoso reconhecer que ela carece de fundamento lógico quando contraposta ao parágrafo único do artigo 944. Na hipótese em que haja a concorrência causal entre condutas de diversos agentes ou do agente e da própria vítima, realmente há como se discutir a eficácia da contribuição causal de cada um e, a partir disso, repartir o ônus indenizatório. Não é esta, contudo, a tela que se desenha na última norma. Ao

\footnotetext{
${ }^{97}$ Diz o referido artigo 945: "Se a vítima tiver concorrido culposamente para o evento danoso, a sua indenização será fixada tendo-se em conta a gravidade de sua culpa em confronto com a do autor do dano".

98 CRUZ, Gisela Sampaio da. Op. cit., p. 333/334: "De acordo com esse terceiro sistema de distribuição do prejuízo [a partir do nexo causal], cada um dos agentes deve suportar o dano na medida em que o tenha produzido, isto é, na proporção em que sua conduta interferiu no evento danoso. Tomase por base aqui não a gravidade da culpa de cada agente, mas a eficácia causal das condutas que concorreram para a produção do prejuízo".

${ }^{99}$ Ibid. p. 336/337.

100 Permita-se uma última referência à obra de CRUZ, Gisela Sampaio da. O Problema do Nexo Causal na Responsabilidade Civil, dados a sua singularidade e o seu cuidadoso tratamento do tema, para a crítica, esta sim adequada, à utilização do termo gravidade da culpa no artigo 945 do Código Civil de 2002, conforme p. 341 e seguintes.
} 
contrário, preleciona o dispositivo acerca do agente que, exclusivamente, causa dano à vítima, a qual não contribuiu de qualquer forma à ocorrência do evento lesivo. Desta forma, há apenas uma causa para a produção do prejuízo, a própria conduta do agente. O comportamento do ofensor é, justamente, a causa eficaz (rectius, exclusiva) à produção do resultado lesivo, em toda a sua extensão. Não haveria espaço para a caracterização da desproporção entre dano e causa, pois aquele teria sempre a justa medida da contribuição eficaz desta. A adoção deste critério mina a aplicabilidade do dispositivo, pois o rouba de sua coesão lógica $^{101}$. Em realidade, o critério eleito pelo legislador é, de fato, a gradação da culpa ${ }^{102}$.

A aparente contradição entre os critérios gravidade da culpa e extensão do dano se afasta com a aplicação de simples regra de hermenêutica, que demanda a interpretação restritiva do disposto no parágrafo único frente à disposição de maior amplitude traduzida no caput do dispositivo ${ }^{103}$. Não se propõe a criação de um sistema dual de quantificação de verbas indenizatórias. A regra é uma e permanece a mesma: mensura-se a indenização pela extensão do prejuízo. Extraordinariamente, entretanto, passa a ser admitida eventual mitigação desta regra, em situações extravagantes em que se aperfeiçoe ante o juiz, ao presidir o caso concreto, em afeição aos preceitos de justiça decorrentes do princípio da solidariedade social, a necessidade de se reduzir tal

\footnotetext{
${ }^{101}$ A crítica quanto à inaplicabilidade do critério da gravidade da culpa à responsabilidade objetiva será examinada no momento apropriado, no item 3.4.1, infra.

${ }^{102}$ Assim entende a majoritária doutrina. Ver, em caráter meramente ilustrativo, TEPEDINO, Gustavo et al. Código Civil interpretado conforme a Constituição da República. vol. II, p. 860: "São situações em que a culpa do agente é insignificante se comparada à extensão do dano. O CC permite, em casos semelhantes, que o juiz reduza eqüitativamente o montante da indenização de modo a conformá-la à intensidade da negligência ou imprudência do ofensor". Em similar propositura, ver FILHO, Sérgio Cavalieri. Op. cit., p. 125; MORAES, Maria Celina Bodin de. Danos à Pessoa Humana, p. 297; GONÇALVES, Carlos Roberto. Op. cit., p. 490/492; e DIREITO, Carlos Alberto Menezes e FILHO, Sérgio Cavalieri. Op. cit., p. 333/334.

103 KONDER, Carlos Nelson. A redução eqüitativa da indenização em virtude do grau de culpa: apontamentos acerca do parágrafo único do art. 944, do Código Civil. In: Revista Trimestral de Direito Civil, n. ${ }^{\circ}$ 29, jan/mar 2007. p. 09: "A contradição entre os dois parâmetros utilizados para a fixação da indenização - extensão do dano e grau de culpa do agente - costuma ser dissipada pelos intérpretes sob a perspectiva de uma norma geral e uma de aplicação excepcional - estrutura típica da técnica legislativa caput-parágrafos".
} 
monta, em atenção à excessiva desproporção entre o tradicional parâmetro da dimensão do dano e a gravidade da culpa do ofensor ${ }^{104}$.

O dispositivo terá aplicação, portanto, quando, por reduzido grau de culpa, o agente perpetrar considerável prejuízo. Deve reconhecer-se na norma, portanto, mais um comprometimento do legislador com crítica formulada por parte da doutrina quanto à possibilidade de se permitir a imputação do dever de indenizar com base apenas na culpa levíssima. Questiona-se dogmaticamente a exigibilidade de um parâmetro de diligência extraordinária, manifesto na culpa levíssima, defendendo alguns que pelos padrões socialmente demandáveis de boa-fé objetiva, apenas a diligência ordinária (e, portanto, as culpas leve e grave) seria juridicamente exigível ${ }^{105}$. A culpa levíssima, de tal maneira, à força maior ou ao caso fortuito se equipararia ${ }^{106}$. Por outro lado, tal lógica implica deixar a vítima sem qualquer ressarcimento e, como se tem insistido ao longo deste estudo, tal postura não se coaduna com as tendências modernas do direito de danos ${ }^{107}$. Ao permitir a redução da indenização em razão da desproporção entre a gravidade da culpa e a dimensão da lesão, a lei encontrou um ponto de inflexão razoável entre ambas as posições. A proteção à vítima preserva a sua máxima envergadura, pois mesmo a culpa levíssima basta para estabelecer o liame de imputação, mas, por outro lado, como se reconhece a

\footnotetext{
${ }^{104}$ Ibid. p. 20: "Se o dispositivo se limita a autorizar a redução - e não a majoração - do montante devido, é sinal de que a sua fixação ainda se pauta pela extensão do dano (como o próprio caput do art. 944 afirma). O grau de culpa pode aparecer apenas como instrumento excepcional e subsidiário de sua mitigação - jamais como sua medida".

105 MORAES, Maria Celina Bodin de. Danos à Pessoa Humana, p. 216/217: "O brocardo latino in lege Aquilia et levissima culpa venit ainda hoje é chamado a justificar a atribuição de responsabilidade em caso de culpa levíssima. Não obstante, a diligência normal, ao se reconduzir ao standard médio, configura o modelo de conduta profissional esperado, não parecendo nem possível nem razoável manter-se uma exigência acima do standard no âmbito da concepção normativa da culpa".

${ }^{106}$ A pesada crítica é de MIRANDA, Francisco Pontes. Tratado de Direito Privado. vol. XXIII. Rio de Janeiro: Borsói, 1958. p. 71: "a chamada culpa levíssima não é culpa; a responsabilidade, aí, é pela força maior ou caso fortuito (...). O que o homem normal, o homem comum, que está nas circunstâncias subjetivas e objetivas do negócio jurídico, sói fazer, ou não fazer, não pode ser infração da linha de licitude. (...) Se o sistema jurídico exige que a culpa levíssima se tenha como causa de responsabilidade, em verdade estabelece responsabilidade pela força maior ou pelo caso fortuito".

${ }^{107}$ Pela qualidade do artigo, faz-se, neste ponto, renovada referência a SCHREIBER, Anderson. Novas Tendências da Responsabilidade Civil Brasileira. In: Revista Trimestral de Direito Civil, vol. 6, n. ${ }^{\circ} 22$, abr/jun 2005. p. $45-69$.
} 
demanda por um grau de diligência que excede o padrão social regular, flexiona-se o dever de indenizar quando for exorbitante a extensão do estrago $^{108}$.

Cumpre, finalmente, ressaltar que, ao contrário de outros diplomas no mundo ${ }^{109}$, optou o ordenamento pátrio em restringir os critérios de apreciação neste processo redutivo exclusivamente à gravidade da culpa do agente (a qual deve desproporcionalmente ocasionar volumoso prejuízo) ${ }^{110}$. Portanto, não se deve buscar na norma guarida para operar decréscimos da monta indenizatória a partir de outros parâmetros, em especial as condições econômico-financeiras tanto do agente, quanto da vítima. Dada a dura realidade pátria, marcada por graves desigualdades acentuadas por um cenário pesaroso de concentração de renda, não é difícil imaginar hipóteses em que anseie o magistrado por intervir em lide marcada por aguda discrepância econômica, pendendo pelo lado mais fraco (seja operando redução além dos estritos limites do dispositivo legal, seja faltando com decréscimo que, nos termos da norma, é perfeitamente cabível). Embora compreensível a angústia do magistrado, esta abordagem é descabida, pois não se presta o dispositivo à compensação de desníveis sócio-econômicos, mas à redistribuição do ônus do prejuízo sofrido (e, portanto, a repartição dos riscos sociais) entre ofendido e ofensor, devendo nortear-se o magistrado pelo princípio da solidariedade social, a partir, exclusivamente, do critério legal: a

\footnotetext{
${ }^{108}$ Acertou o legislador, entretanto, ao redigir o dispositivo, em não mencionar expressamente este grau de culpa, em específico. Em determinados casos, o juiz poderá verificar a necessidade de se operar a equânime redução, em razão da excessiva desproporção entre o dano extenso e a gravidade da culpa do agente, mesmo quando este obra em culpa leve, não levíssima. Apenas a culpa grave, que ao dolo se equipara, é que se exclui, peremptoriamente, do escopo de aplicabilidade do dispositivo.

${ }^{109}$ Para mera ilustração, comumente refere-se, comparativamente, ao diploma civilista luso, que traz, em seu artigo $494^{\circ}$, disposição similar, mas não idêntica. O dispositivo português faz menção expressa às situações econômicas de ofensor e ofendido e às demais circunstâncias do caso. Ipsis literis, eis a norma patrícia: "Quando a responsabilidade se fundar na mera culpa, poderá a indemnização ser fixada, equiitativamente, em montante inferior ao que corresponderia aos danos causados, desde que o grau de culpabilidade do agente, a situação económica deste e do lesado e as demais circunstâncias do caso o justifiquem".

110 KONDER, Carlos Nelson. Op. cit., p. 12/13: "Finalmente, é importante observar que a nova faculdade de redução equiitativa da indenização prevista no art. 944, parágrafo único, do Código Civil também se distingue de outros dispositivos similares encontrados no direito estrangeiro por restringirse à utilização do grau de culpa como parâmetro de ponderação”.
} 
desproporção excessiva entre o grau de culpa da conduta do último e as dimensões do dano causado ${ }^{111}$.

\subsection{2 - Excessiva desproporção}

Como já reiterado inúmeras vezes, para se operar a redução proposta no parágrafo único do artigo 944, não basta a simples constatação de que o ofensor tenha obrado com um grau tênue de culpa. É necessária a configuração, a partir deste comportamento levemente desviante, de prejuízo de extensas dimensões, caracterizando, conforme a preceituação normativa, excessiva desproporção ${ }^{112}$.

A demanda por uma discrepância abrasadora é pedra de toque à compreensão do dispositivo, pois é a partir deste elemento que se evidencia com clareza a intenção legislativa de fornecer ao judiciário um mecanismo para, no caso concreto, ajustar, entre as partes envolvidas, o ônus indenizatório, compreendido este num efeito demasiadamente nocivo, provocado de maneira desmesurada, por erro de conduta perpetrado por comportamento que se afasta do parâmetro socialmente esperado apenas num baixo grau. Permite-se, desta forma, que seja aliviado o fardo do prejuízo entre ofensor e ofendido, pelo seu adequado compartilhamento. Evidencia-se, em igual medida, como o disposto ainda pretende assegurar a tutela protetora da vítima como elemento primordial do sistema de responsabilidade civil, pois, ao impor a necessidade de uma exagerada desproporção entre os critérios, a norma cerceia ainda mais a sua esfera de aplicabilidade. Corriqueiramente, a tendência que se verifica é a de

\footnotetext{
111 TEPEDINO, Gustavo et al. Código Civil interpretado conforme a Constituição da República. vol. II, p. 861: "Não se trata de compensar desníveis econômicos, mas tão somente de reduzir eqüitativamente o valor da indenização para que a excessiva desproporção entre a culpa do agente e a extensão do dano seja dividida, à luz do princípio constitucional da solidariedade".

${ }^{112}$ DIREITO, Carlos Alberto Menezes e FILHO, Sérgio Cavalieri. Op. cit., p. 338: "é necessário levar em conta que o elemento-chave para reduzir a indenização é a constatação da 'excessiva desproporção'; ausente esta, não incide o parágrafo único”. No mesmo sentido, KONDER, Carlos Nelson. Op. cit., p. 21: "Se o grau de culpa tivesse se tornado parâmetro para a fixação da indenização, esta teria que estar fixada sempre em proporção com aquele. Contudo, não é qualquer desproporção que autoriza a intervenção eqüitativa do juiz, mas apenas aquela que se revela excessiva. Somente em casos de dano de alta ou altíssima magnitude causados por condutas levíssima ou levemente culposas poderá ocorrer o arrefecimento do dever de indenizar".
} 
condutas dolosas ou gravemente culposas provocarem os danos mais extensos, enquanto, por outro lado, os comportamentos levemente culposos é que trazem os prejuízos de menor monta ${ }^{113}$. Assim, no maior número de ocasiões, em que as condutas levemente culposas trarão resultados nocivos de expressividade menos considerável, preservar-se-á a imposição do caput do artigo 944, devendo o quantum indenizatório fixar-se pela estrita extensão do dano, sem se admitir qualquer mitigação.

Pela inclusão no dispositivo da imperiosidade de demonstração de desproporção excessiva, pode delinear-se com certa clareza que a vontade da lei é, de fato, restringir a sua aplicabilidade apenas a hipóteses verdadeiramente excepcionais $^{114}$, em que, de fato, se verifica a necessidade de se operar efetiva redistribuição dos ônus e riscos sociais entre agressor e agredido, em estrita observância aos preceitos do ordenamento, especialmente ao paradigma constitucional da solidariedade social.

\subsection{3 - Eqüidade}

Eqüidade é um termo equívoco, referencia-se a um instituto que designa dois esforços jurídicos distintos. A eqüidade se pode referir ao procedimento jurisdicional de supressão de uma lacuna do ordenamento pela formulação de um preceito no caso concreto, constituindo, desta maneira, um precedente; ou se pode fazer alusão ao instrumento da hermenêutica que busca traduzir um ajustamento, uma efetiva adequação, da norma geral à situação de fato, a cumprir, desta forma, um maior aperfeiçoamento dos preceitos da justiça ${ }^{115}$.

\footnotetext{
${ }^{113}$ CRUZ, Gisela Sampaio da. Op. cit., p. 333.

${ }^{114}$ KONDER, Carlos Nelson. Op. cit., p. 20: “A prerrogativa, entretanto, é limitada em diversos níveis: serve apenas para reduzir o montante (não aumenta-lo); só se aplica em casos - excepcionais - de 'excessiva desproporção' e só autoriza a ponderação com base na gravidade da culpa (aparentemente excluindo outros parâmetros)".

115 MAXIMILIANO, Carlos. Hermenêutica e aplicação do direito. $18^{\mathrm{a}}$ Ed. Rio de Janeiro: Forense, 1999. p. 172: "Desempenha a Eqüidade o duplo papel de suprir as lacunas dos repositórios de normas, e auxiliar a obter o sentido e alcance das disposições legais. Serve, portanto, à Hermenêutica e à Aplicação do Direito".
} 
Na primeira hipótese, comum a ambos o direito codificado positivista e o direito consuetudinário - embora mais comum neste - tem-se um mecanismo para o preenchimento das lacunas do ordenamento jurídico, a ser operado pelo magistrado no exercício da jurisdição, direcionando-se à concreta solução de conflitos acerca dos quais silenciou a lei ${ }^{116}$.

Na segunda variável, não mais se cogita de ausência normativa, mas de uma conformação do texto legal aos preceitos de justiça que informam o ordenamento, orientando a aplicação da lei à produção de resultados socialmente mais benéficos e eficazes, aperfeiçoando a norma além de seu estrito rigor, atenuando-a, dando-lhe a adequada roupagem, no caso concreto, sem, entretanto, descaracterizá-la ${ }^{117}$.

O parágrafo único do artigo 944 do Código Civil vigente, ao referir-se à possibilidade de o juiz reduzir, eqüitativamente, as verbas indenizatórias, refere-se, perceptivelmente, à segunda acepção do termo. Pretende a norma que, ao se aplicar a redução em discussão, se o faça em observância a estritos termos de equanimidade, atentando aos ditames da justiça ${ }^{118}$.

Pretende-se, em suma, que o magistrado, ao jurisdicionar, o faça em atenção às particularidades do caso sob análise ${ }^{119}$, respeitando os preceitos constitucionais, para tracejar, no concreto, a repartição do ônus imposta pela norma, em tradução do paradigma solidarista. O juízo equânime, reto, é aquele que redistribuir a carga indenizatória entre ofensor e ofendido na justa medida do que a cada um compete ${ }^{120}$, cumprindo uma avaliação estritamente meritória,

\footnotetext{
116 Ibid. p. 174.

117 Ibid. p. 175: "Não se recorre à Eqüidade senão para atenuar o rigor de um texto e o interpretar de modo compatível com o progresso e a solidariedade humana; jamais será a mesma invocada para se agir, ou decidir, contra prescrição clara e prevista" (grifos no original).

118 DIREITO, Carlos Alberto Menezes e FILHO, Sérgio Cavalieri. Op. cit., p. 334: “A noção de eqüitativo aqui deve ser tomada como julgamento justo, senso de justiça, respeito à igualdade dos direitos das partes, para a imposição de uma condenação suficiente à reparação do dano".

${ }_{119}$ MAXIMILIANO, Carlos. Op. cit., p. 175.

${ }^{120}$ AGUIAR, Ruy Rosado de apud DIREITO, Carlos Alberto Menezes e FILHO, Sérgio Cavalieri. Op. cit., p. 335: "O direito, que é a obra da justiça para estabelecer uma relação de igualdade entre as partes, na justa proporção do que cabe a um e cabe ao outro, permite ao juiz aplicar, em certos casos, a eqüidade.
} 
a partir dos referenciais trazidos pelo ordenamento. É dever do juiz ponderar a necessidade de se contrabalançar a tutela protetora da vítima, que não pode restar desassistida, e o cuidado com o agente nocivo, cujo desvio se deu em escala reduzida, de forma que o ordenamento reconhece a injustiça da obrigálo a arcar com todo o prejuízo ${ }^{121}$, para então operar um decréscimo razoável, proporcional, equânime, do quantum debeatur, devendo, sempre, fundamentar exaustivamente a sua decisão.

Mais uma vez, cumpre clarificar que o dispositivo não se presta a compensação de desigualdades sociais, não devendo o seu aplicador imiscuir no juízo eqüitativo critérios econômico-financeiros, tanto em relação à vítima, quanto ao ofensor. $\mathrm{O}$ dispositivo - o sistema de responsabilidade civil em sua totalidade, aliás - não se presta à redistribuição de riquezas ou à correção de desigualdades históricas, mas à socialização de riscos.

O recurso à eqüidade é expediente comum na prática legislativa pátria, decorrente na confiança depositada no julgador de melhor exprimir, no caso concreto, a preocupação maior do direito, que é o perfazimento da justiça ${ }^{122}$.

\section{3 - A interpretação do dispositivo}

A interpretação do dispositivo consubstanciado no parágrafo único do artigo 944 do Código Civil de 2002 tem sido objeto de disputa e um dos pontos mais controvertidos, em doutrina. De um lado, há aqueles que receberam o dispositivo com ressalvas, e pretendem realizar a sua interpretação da maneira mais restritiva possível ${ }^{123}$. Do outro lado, enfileiram-se os defensores da ampla

\footnotetext{
${ }^{121}$ FILHO, Sérgio Cavalieri. Op. cit., p. 125: "Aqui também terá que se valer do bom senso, do equilíbrio, da razoabilidade, de sorte a não deixar a vítima no desamparo, nem levar o causador do dano à insolvência".

${ }^{122}$ Dentre outras referências ao juízo eqüitativo do magistrado, podem citar-se, a caráter meramente exemplificativo, as disposições trazidas pelos artigos 413; 738, § único; 928, § único; e 953, § único; todos do Código Civil de 2002.

${ }^{123}$ TEPEDINO, Gustavo et al. Código Civil interpretado conforme a Constituição da República. vol. II, p. 860: "O dispositivo, contudo, deve ser, visto com cautela e interpretado em estrita conformidade com sua inspiração, sendo recomendável restringir sua aplicação".
} 
interpretação do dispositivo, defendendo a ampliação, seja pela inclusão de novos critérios para se operar a redução indenizatória ${ }^{124}$, seja para defender a possibilidade de inclusão de um caráter punitivo no montante da indenização $^{125}$.

Como dito anteriormente, o parágrafo único do artigo 944 comporta exceção ao princípio da reparação integral ${ }^{126}$. A necessidade de se tutelar inteiramente a vítima é o propósito elementar do sistema de responsabilidade civil, e a prelação que encabeça o artigo 944 do Código Civil de 2002 é expressão desta razão geral, constituindo-se como a regra. A possibilidade de redução do quantum indenizatório, por sua vez, está atrelada à necessidade social, em razão do paradigma solidarista, de, em algumas ocasiões, resguardar a figura do ofensor, configurando, assim, uma exceção ${ }^{127}$. Daí, inclusive, a estruturação legislativa, que dispõe, no caput do artigo, o preceito genérico, para, em seu parágrafo, oferecer a disposição excepcional ${ }^{128}$.

Em se compondo a norma desta forma, a hermenêutica determina que se deva interpretar restritivamente a disposição excepcional, por carregar norma que não se coaduna com a finalidade transposta na regra geral ${ }^{129}$.

\footnotetext{
${ }^{124}$ RODRIGUES, Silvio apud KONDER, Carlos Nelson. Op. cit., p. 24: "examinando o caso concreto, as circunstâncias pessoais das partes e as materiais que o circundam, o juiz fixará a indenização que entender adequada. Poderá fazê-la variar conforme as posses do agente causador do dano, a existência ou não do seguro, o grau de culpa e outros elementos particulares à hipótese em exame".

${ }^{125}$ FIÚZA, Ricardo (Coord.). Novo Código Civil Comentado. $4^{\text {a }}$ Ed. São Paulo: Saraiva, 2005. p. 857: "Saliente-se, ainda, que este artigo, ao adotar a gradação da culpa do agente no cálculo da indenização, confere apoio legal ao caráter punitivo da reparação de danos". Antevendo a possibilidade, sem, entretanto, diretamente defendê-la, VENOSA, Silvio de Salvo. Direito Civil. vol. I, p. 595: "É de se prever que está aberta a válvula, inclusive, para a exacerbação da indenização, mormente nos danos morais e nos casos de culpa grave, o que, aliás, harmoniza-se com as novas tendências doutrinárias".

${ }^{126}$ STOCO, Rui. Op. cit., p. 141.

${ }^{127}$ Esclarece, ao fornecer a formulação genérica, MAXIMILIANO, Carlos. Op. cit., p. 225: "Estriba-se a regra numa razão geral, a exceção, numa particular; aquela baseia-se mais na justiça, esta, na utilidade social, local ou particular. As duas proposições devem abranger coisas da mesma natureza; a que mais abarca há de constituir a regra; a outra, a exceção" (grifos no original).

${ }^{128}$ KONDER, Carlos Nelson. Op. cit., p. 09.

129 MAXIMILIANO, Carlos. Op. cit., p. 227: "As disposições excepcionais são estabelecidas por motivos ou considerações particulares, contra outras normas jurídicas, ou contra o Direito comum; por isso não se estendem além dos casos e tempos que designam expressamente. Os contemporâneos preferem encontrar o fundamento desse preceito no fato de se acharem preponderantemente do lado do princípio geral as forças sociais que influem na aplicação de toda regra positiva, como sejam os fatores sociológicos" (grifos no original).
} 
Em função desta necessidade de interpretação estrita, restam vedados outros mecanismos de interpretação, de caráter extensivo, que buscam alargar o conteúdo da norma.

Valer-se da interpretação extensiva, para incluir outros critérios, como a capacidade econômico-financeira das partes envolvidas - ofensor e ofendido -, a pré-existência de contrato de seguro firmado por qualquer das partes, além de eventuais outras circunstâncias fáticas concernentes às pessoas e ao meio, é posição que se prova, portanto, definitivamente comprometida, pois implicaria na redução do montante indenizatório em circunstâncias outras que não as expressamente autorizadas legalmente, em confronto com o princípio da reparação integral, o qual subsiste como regra geral $^{130}$.

Da mesma maneira, as proposições de se interpretar o dispositivo de maneira a abarcar a possibilidade de se ampliar, ao contrário de reduzir, o volume das verbas indenizatórias, a partir da percepção de que o agente obrou dolosamente ou com elevado grau de culpa, também não encontram guarida na hermenêutica jurídica e ficam prejudicadas. A sustentação de que a mera menção ao grau de culpa bastaria para reconhecer a aceitação de parâmetros punitivos na quantificação indenizatória, mais uma vez, não encontra morada na dicção do dispositivo, pois este se exaure na estrita possibilidade de redução do quantum, não albergando a hipótese reversa de extrapolação dos limites do dano causado. Assim, operando aquém dos valores estritamente reparatórios não há espaço para se falar de pretensões punitivas ${ }^{131}$.

Fica igualmente proscrita a possibilidade de supressão da indenização nos casos em que a conduta colimada de culpa levíssima redundar em danos de proporções catastróficas.

\footnotetext{
${ }^{130}$ KONDER, Carlos Nelson. Op. cit. p. 20.

131 MORAES, Maria Celina Bodin de. Danos à Pessoa Humana, p. 297: "Tendo empregado o legislador de 2002 o verbo 'reduzir', e não o verbo 'ponderar', o juiz não poderá majorar, além da medida do dano, a indenização, em caso de responsabilidade contratual, indicando, mais uma vez, a recusa do legislador brasileiro em penalizar o devedor, mesmo se este agiu com dolo".
} 


\section{4 - A aplicabilidade do dispositivo}

\subsection{1 - Responsabilidade civil subjetiva e objetiva}

O escopo de aplicabilidade do dispositivo também é objeto de debate na doutrina. A escolha legislativa pela gravidade da culpa, elemento de caráter eminentemente subjetivo, como critério a se considerar na operação da redução das verbas indenizatórias, nos termos do parágrafo único do artigo 944, levou à divergências dogmáticas quanto à possibilidade de se valer do dispositivo em hipóteses de responsabilidade civil objetiva, ou se deveria ficar restrito o seu uso às hipóteses de responsabilidade civil subjetiva.

Claramente ilustra a dificuldade apresentada pelo tema a mudança de posições da Jornada de Direito Civil, promovida pelo Centro de Estudos do Conselho da Justiça Federal. Em setembro de 2002, após reunião em Brasília, formulou-se o Enunciado n. 46, que determina ${ }^{132}$ :

“A possibilidade de redução do montante da indenização em face do grau de culpa do agente, estabelecida no parágrafo único do art. 944 do novo Código Civil, deve ser interpretada restritivamente, por representar uma exceção ao princípio da reparação integral do dano, não se aplicando às hipóteses de responsabilidade objetiva" (grifou-se).

Em outubro de 2006, entretanto, em nova reunião, optou-se por remover este último trecho do enunciado, em destaque, alinhando-se à posição de outros doutrinadores, que enxergam a possibilidade de aplicação indistinta da norma a ambos os campos da responsabilidade civil ${ }^{133}$.

A aplicabilidade do dispositivo à responsabilidade civil subjetiva não é objeto de disputa. Concentra-se a divergência na extensão da proposição à responsabilidade civil objetiva em razão de esta esfera do direito de danos

\footnotetext{
${ }^{132}$ FILHO, Sérgio Cavalieri. Op. cit., p. 125

${ }^{133}$ KONDER, Carlos Nelson. Op. cit., p. 22.
} 
desprezar a existência da culpa, o elemento subjetivo, para a caracterização do nexo de imputação e, conseqüentemente, do dever de indenizar ${ }^{134}$.

A distinção provocou uma cisão na doutrina.

Por um lado, sustentou-se, afastando a aplicabilidade do dispositivo à responsabilidade civil objetiva, que, na medida em que se prescinde da culpa para imputar o dever de reparação ao agente, não há cabimento que se a evoque (ou, especificamente, a sua pequena gravidade) como fundamento para eventual redução deste ônus ${ }^{135}$.

Por outro lado, em favor da aplicabilidade indiferenciada da norma a ambas as esferas da responsabilidade civil, subjetiva e objetiva, argumenta-se que, na medida em que o parágrafo único do artigo 944 se presta a abrandar o ônus dos agentes que obrassem em reduzida culpa, haveria uma contradição lógica em se negar o emprego do dispositivo às hipóteses de responsabilidade objetiva, em que, muitas vezes, impõe-se o dever de indenizar a quem se conduziu sem culpa alguma ${ }^{136}$.

Em verdade, não há nenhuma contradição lógica no disposto. A leitura da norma como um preceito que autoriza a premiação do agente levíssima ou levemente culpado pela redução das verbas indenizatórias está intimamente vinculada a velhos paradigmas, que enxergavam o sistema de responsabilidade civil como instrumento de moralização da conduta social, e, portanto, em defasagem com as modernas inclinações do sistema, que, em conformidade aos

\footnotetext{
${ }^{134}$ FILHO, Sérgio Cavalieri. Op. cit., p. 143: "na responsabilidade objetiva teremos uma conduta ilícita, o dano e o nexo causal. Só não será necessário o elemento culpa, (...). Esta pode ou não existir, mas será sempre irrelevante para a configuração do dever de indenizar.".

135 KONDER, Carlos Nelson. Op. cit., p. 21: "De fato, o terceiro limite contido no dispositivo, é eleição do grau de culpa como parâmetro a ser utilizado pelo juiz na mitigação do dever de indenizar. Disto decorre, em conseqüência, a sua aplicabilidade restrita às hipóteses de responsabilidade subjetiva, pois a consideração do grau de culpa não condiz com as hipóteses de responsabilidade objetiva, que prescindem da existência de culpa" (grifos no original).

136 STOCO, Rui. Op. cit., p. 1.189: "Perceba-se a contradição lógica: nas condutas em que o pressuposto da responsabilidade é a culpa, deve-se verificar a sua graduação (intensidade do dolo, culpa grave, leve e levíssima) para dimensionar o quantum da indenização que, então, poderá ficar aquém do verdadeiro prejuízo. Mas nas hipóteses em que basta a conduta, o nexo de causalidade e o resultado danoso, em que se dispensa a indagação de culpa, o agente responderá por inteiro, ainda que não tenha agido com culpa".
} 
preceitos da tábua axiológica constitucional, pretende reconhecer no direito de danos um mecanismo de redistribuição dos riscos da vida contemporânea em sociedade.

Sujeitando-se, pelo contrário, o dispositivo a uma interpretação que se conforme aos atuais paradigmas do ordenamento pátrio, tem-se o necessário afastamento da responsabilidade civil objetiva do escopo de aplicabilidade da norma.

Afinal, não é função do parágrafo único do artigo 944 conceder prêmio de consolação ao agente obrigado a indenizar por conduta cuja censurabilidade social é reduzida, e sim proporcionar o remanejamento do prejuízo sofrido, implicando, também, que, em determinadas circunstâncias, o risco de danos deve ser simultaneamente suportado por ambos ofensor e ofendido.

Nestes termos, portanto, não há que se cogitar a viabilidade da limitação do quantum debeatur em hipóteses de responsabilidade civil objetiva, cujo fundamento é, precisamente, o exercício de atividade que, por suas próprias características, contribui definitivamente para a elevação dos riscos sociais de produção de danos ${ }^{137}$.

\subsection{2 - Dano patrimonial e extrapatrimonial}

Também controverte os debates doutrinários a aplicabilidade da norma às distintas espécies de dano. Parte da doutrina defende que o dispositivo se aproveita indiscriminadamente a ambas as hipóteses ${ }^{138}$, devendo aplicá-lo o magistrado tanto ao dano patrimonial, quanto ao dano extrapatrimonial. Outro

\footnotetext{
${ }^{137}$ TEPEDINO, Gustavo et al. Código Civil interpretado conforme a Constituição da República. vol. II, p. 861: "No que diz respeito à culpa como parâmetro para a redução da indenização, é de se considerar, todavia, que o conceito não se aplica à responsabilidade objetiva. Como antes explicado, o parágrafo único do art. 944 vem tutelar justamente as excepcionais hipóteses em que se recomenda a divisão do risco social entre o autor do dano e a vítima. Ora, a responsabilidade objetiva é reservada pelo ordenamento brasileiro às atividades que geram, por si só, risco social excessivo (...). Seria contraditório permitir que, naquelas hipóteses em que o legislador considerou que a atividade gerava risco excessivo e por isto dispensou a prova da culpa do agente, o juiz levasse em conta a baixa intensidade da culpa para reduzir a indenização, relançando parte do risco sobre a vítima do dano".

${ }^{138}$ KONDER, Carlos Nelson. Op. cit., p. 14 e seguintes.
} 
segmento da doutrina defende que se restrinja a aplicabilidade da disposição legal apenas às hipóteses de dano patrimonial ${ }^{139}$. E, por fim, há ainda aqueles que prelecionam a exclusiva utilização do parágrafo único do artigo 944 aos casos de dano extrapatrimonial ${ }^{140}$.

Como já mencionado, impõem-se distintos critérios para a reparação do prejuízo, em razão de a sua natureza revelar-se estritamente patrimonial ou extrapatrimonial. O dano material é passível de mensuração econômica ${ }^{141}$, daí a comum afirmativa de que a indenização se calcula pela extensão do dano, esgotando-se a investigação do prejuízo numa operação de índole meramente aritmética, a qual resta facilitada pelas inúmeras possibilidades trazidas por distintas formas de prova pericial ${ }^{142}$. O dano imaterial, por sua vez, não deixa este rastro, não se presta a uma mensuração escorada em elementos e indícios técnicos ${ }^{143}$. Corretamente, tem-se o dano extrapatrimonial como uma espécie incomensurável, estranha à avaliação pura e simplesmente matemática. Diante da impossibilidade de mensurá-lo, propõe-se que opere o juiz um arbitramento, estimando um valor apto à compensação do prejuízo sofrido ${ }^{144}$.

Dentre os critérios para balizamento deste montante, novamente há dissenso dogmático.

A parcela majoritária da doutrina reconhece um caráter dúplice aos danos extrapatrimoniais, que abrangeria, simultaneamente, duas dimensões: uma de natureza compensatória, outra de matiz punitivo. Reconhece esta doutrina a existência, no espírito humano, duma ânsia vingativa que também

\footnotetext{
${ }^{139}$ FIÚZA, Ricardo (Coord.). Op. cit., p. 854 e seguintes.

${ }^{140}$ CUNHA, Leonardo Nascimento. A aplicabilidade do art. 944, parágrafo único, do Código Civil de 2002 aos danos materiais. Disponível em http://jus2.uol.com.br/doutrina/texto.asp?id=9568. Acesso em 19 de outubro de 2007, em especial itens II.i e II.ii.

${ }^{141}$ VENOSA, Silvio de Salvo. Direito Civil. vol. II, p. 257 a 261.

${ }^{142}$ DIREITO, Carlos Alberto Menezes e FILHO, Sérgio Cavalieri. Op. cit., p. 338/339.

${ }^{143}$ Em verdade, como já aduzido, tamanha é a dificuldade de manifestação do dano extrapatrimonial, que a espécie sequer se submete à prova, devendo a sua ocorrência decorrer insitamente da narrativa dos fatos. Neste sentido, ver FILHO, Sergio Cavalieri. Op. cit., p. 101.

${ }^{144}$ TEPEDINO, Gustavo et al. Código Civil Interpretado Conforme a Constituição da República. vol. I, p. 337: "Não sendo possível atingir matematicamente um resultado econômico preciso, o quantum da indenização por dano moral é deixado ao arbitramento dos juízes".
} 
precisa ser aplacada para que a satisfação do dano extrapatrimonial alcance, de fato, a compensação a que se presta ${ }^{145}$. Ademais, a punição de comportamentos mal-intencionados ou grosseiramente culposos contribuiria para a educação e moralização da coletividade, conferindo, assim, à indenização punitiva o mérito de contribuir para a prevenção de novas condutas danosas por meio do desestímulo financeiro. Atentando a esta natureza dual, o arbitramento do dano moral tomaria por critérios a gravidade da culpa do agente e a situação econômica de ambas as partes (critérios de inclinação punitiva), além da gravidade do dano e as condições pessoais da vítima (critérios que observam o papel compensatório) ${ }^{146}$.

Minoritariamente, defende-se a preservação da essência compensatória do instituto, expurgando a atual tendência de se atribuir caráter punitivo ao dano extrapatrimonial sem fundamento legal que o autorize. Esta corrente entende que propósitos punitivos são insitamente alheios à responsabilidade civil. Sustenta-se que o giro conceitual operado constitucionalmente, com elevação da dignidade humana à condição de fundamento da república, alterou o eixo do sistema, ora centrado na figura da vítima, não mais no ofensor, contribuindo ainda mais para o afastamento deste caráter punitivo genérico. $\mathrm{O}$ paradigma solidarista repousa na tutela do lesado, não na imposição de medidas penais ao ofensor $^{147}$. Como critérios de arbitramento, portanto, são admitidas apenas a

\footnotetext{
${ }^{145}$ SILVA, Caio Mario Pereira da. Responsabilidade Civil, p. 315/316: "na reparação por dano moral estão conjugados dois motivos, ou duas concausas: I - punição ao infrator pelo fato de haver ofendido um bem jurídico da vítima, posto que imaterial; II - pôr nas mãos do ofendido uma soma que não é o pretium doloris, porém o meio de lhe oferecer oportunidade de conseguir uma satisfação de qualquer espécie, seja de ordem intelectual ou moral, seja mesmo de cunho material, o que pode ser obtido "no fato' de saber que esta soma de dinheiro pode amenizar a amargura da ofensa e de qualquer maneira $o$ desejo de vingança" (grifos no original).

${ }^{146}$ MORAES, Maria Celina Bodin de. Danos à Pessoa Humana, p. 295/296: “Com poucas variações, podem ser considerados aceites os seguintes dados para a avaliação do dano moral: i) o grau de culpa e a intensidade do dolo do ofensor (a dimensão da culpa); ii) a situação econômica do ofensor; iii) a natureza, a gravidade e a repercussão da ofensa (a amplitude do dano); iv) as condições pessoais da vítima (posição social, política, econômica); e v) a intensidade de seu sofrimento".

${ }^{147}$ Para a leitura dos danos extrapatrimoniais na perspectiva civil constitucional, recomenda-se obra reiteradamente citada neste trabalho: MORAES, Maria Celina Bodin de. Danos à Pessoa Humana: Uma Leitura Civil-Constitucional dos Danos Morais. Rio de Janeiro, Renovar, 2003.
} 
gravidade do dano e as condições pessoais (mas não as econômico-financeiras) da vítima ${ }^{148}$.

A existência de diferenciados critérios a se considerar no processo de quantificação das verbas reparatórias das distintas espécies de dano, bem como a controvérsia acerca de que elementos trabalhar no momento do arbitramento dos danos extrapatrimoniais acabou por provocar nova divergência doutrinária acerca da aplicabilidade da norma.

Um segmento expressivo da doutrina celebrou a dicção do parágrafo único do artigo 944, defendendo o entendimento de que a opção legislativa por introduzir o grau da culpa no processo de quantificação da indenização representava um reconhecimento expresso em texto legal da existência de um caráter punitivo no dano extrapatrimonial. $\mathrm{Na}$ medida em que apenas em seu arbitramento se pode evocar a gravidade da culpa como critério quantitativo, o dano material estaria fora do alcance da disposição legal ${ }^{149}$.

Esta posição, contudo, resta fragilizada, pois, como já exposto, a norma não se presta à interpretação a contrario sensu. Impõe-se a interpretação restritiva, e, conseqüentemente, suprime-se a possibilidade de ampliação do montante da indenização. Desta maneira, não há como se pretender reconhecer no dispositivo um caráter punitivo. Tal vinculação está em descompasso com as determinações da hermenêutica e, portanto, não se sustenta.

\footnotetext{
${ }^{148}$ PERLINGIERI, Pietro. Op. cit., p. 174: "Ela [a avaliação eqüitativa do dano extrapatrimonial] não pode consistir em uma operação arbitrária, mas em uma avaliação discricionária que leve em consideração as particularidades existenciais da pessoa, isto é, aquelas exigências conaturais à sua personalidade e atinentes ao seu livre desenvolvimento e às suas intrínsecas manifestações".

${ }_{149}$ CUNHA, Leonardo Nascimento. Op. cit., p. 05: "Insisto, neste desiderato, e desde logo, que somente se terá como constitucional o parágrafo único do art. 944, do CC/02 - salvando-se assim a utilidade da norma -, caso sua aplicação restrinja-se à valoração do ressarcimento da responsabilidade civil pedagógica, limitando sua aplicabilidade ao segundo critério de indenizabilidade moral - punição do agente" (grifos no original). E arremata, na página seguinte: "Continuando com a proposta trazida a lume, qual seja, a de se vislumbrar alguma aplicabilidade constitucional do dispositivo de lei em testilha (art. 944, parágrafo único, CC/02) às duas hipóteses de dano existentes, exsurge esta outra indagação: será possível aplicarmo-lo às hipóteses de indenização por dano material? A resposta que defendemos é negativa" (grifos no original).
} 
Outro segmento expressivo da doutrina, em via reversa, entendeu que a escolha legislativa pela locução "extensão do dano", tanto no caput, quanto no parágrafo único do artigo 944, deve ser entendida como a estipulação de uma correlação direta entre quantum debeatur e a mensurabilidade do prejuízo, o que excluiria, peremptoriamente, o dano extrapatrimonial do escopo da disposição, espécie que não dispõe deste atributo. Assim, a disciplina do arbitramento do dano extrapatrimonial permaneceria afeita apenas aos dizeres da doutrina e da jurisprudência, livre de critérios normativos ${ }^{150}$, enquanto o parágrafo único se restringiria, portanto, exclusivamente às hipóteses de dano estritamente material $^{151}$.

Paralelamente, uma facção doutrinária sustentou a aplicação indistinta do dispositivo a ambas as espécies de dano. Deve reconhecer-se na norma a intenção do legislador de positivar o princípio da reparação integral, comum a ambos os danos patrimonial e extrapatrimonial ${ }^{152}$. Apesar de referir-se a extensão do dano diretamente, em sua ultima ratio, a norma traria uma residual possibilidade de se excetuar o princípio geral, inexistindo razões para limitá-la a apenas uma das espécies de dano.

Em verdade, a despeito de verdadeira a assertiva de que o princípio da reparação integral se aplica às duas espécies de dano extrapatrimonial, isto não basta para incluir os últimos no escopo de aplicabilidade do dispositivo, a qual, corretamente, restringe-se aos danos materiais.

\footnotetext{
${ }^{150}$ NETO, Eugênio Facchini. Da responsabilidade civil no novo Código. In: SARLET, Ingo Wolfgang (Org.). O Novo Código Civil e a Constituição. Porto Alegre: Livraria do Advogado, 2003. p. 184: "Saliente-se que o referido dispositivo [o parágrafo único do artigo 944] não se aplica aos danos extrapatrimoniais, permanecendo inalterada a recomendação de se levar em consideração, no arbitramento do valor dos mesmos, dentre outros fatores (como a intensidade da culpa, as circunstâncias do evento, a duração dos efeitos, a repercussão dos mesmos na vida da vítima, etc.), também a condição socioeconômica tanto da vítima, quanto do agente".

${ }^{151}$ FIÚZA, Ricardo (Coord). Op. cit., p. 855: "O dispositivo [artigo 944] é, no entanto, insuficiente, já que seu caput se adapta somente ao dano material e não está adequado ao dano moral".

${ }^{152}$ KONDER, Carlos Nelson. Op. cit., p. 14: "O princípio da reparação integral do dano, como foi visto, é tradicionalmente reconhecido em nosso ordenamento e vem, agora, expresso no caput do artigo 944 do Código Civil, embora excepcionado pelo seu parágrafo único. (...) A confusão que orbita a reparação do dano moral acaba por nublar a percepção de muitos da aplicação, também nesta seara, do princípio da reparação integral”.
} 
O motivo para esta restrição, entretanto, não reside exclusivamente na terminologia empregada pelo dispositivo, mas pela necessidade de conformá-lo à axiologia que harmoniza o sistema.

Como dito e reiterado, o parágrafo único do artigo 944 não tem como função premiar o comportamento eivado de pouca culpa, em atenção à menor censurabilidade da conduta nociva. Pelo contrário, ele se presta à redistribuição dos ônus sociais, considerando que devem repartir-se, em determinadas circunstâncias, os riscos e os prejuízos entre o agente lesivo e a vítima, em observância ao princípio da solidariedade social.

Tal repartição terá cabimento apenas na seara dos danos patrimoniais, na qual será possível a caracterização de eventual conjuntura em que se reconheça a necessidade de se permitir que o resultado lesivo seja redistribuído e partilhado entre os patrimônios de ofensor e vítima.

No campo dos danos extrapatrimoniais, o princípio da solidariedade social não poderá ser evocado como fundamento à realocação dos ônus e riscos sociais porque se estarão contrapondo, de um lado, a dimensão patrimonial do ofensor, e, do outro, a estrutura moral do ofendido, que teve lesado um direito que compõe a sua personalidade.

Em razão do princípio da dignidade humana (artigo $1^{\circ}$, III, CRFB/88), que se erige como preceito fundamental do ordenamento, reconhecido constitucionalmente como fundamento da república, e cláusula geral de tutela da pessoa, não se pode admitir, na ponderação de interesses em conflito, a prevalência de questões estritamente patrimoniais quando opostas a situações jurídicas existenciais ${ }^{153}$.

\footnotetext{
${ }^{153}$ MORAES, Maria Celina Bodin de. O Princípio da Dignidade Humana, p. 53: "em todas as relações privadas nas quais venha a ocorrer um conflito entre uma situação jurídica subjetiva existencial e uma situação jurídica patrimonial, a primeira deverá prevalecer, obedecidos, dessa forma, os princípios constitucionais que estabelecem a dignidade da pessoa humana como valor cardeal do sistema”.
} 
Desta forma, enquanto no campo dos danos materiais é possível se administrar, no caso concreto, quando a solidariedade social assim impingir, o compartilhamento entre os patrimônios de ofensor e ofendido dos ônus e riscos sociais, ao trazer a norma para a esfera dos danos extrapatrimoniais, ela se revela inócua, pois contrapostos estão interesses materiais do ofensor e os direitos da personalidade, imateriais, do ofendido, e estes, por força da cláusula geral de tutela da dignidade da pessoa, sempre terão preponderância ${ }^{154}$.

Nestes termos, destarte, não há como se defender a aplicabilidade do parágrafo único do artigo 944 aos danos de natureza extrapatrimonial, pois a precípua superioridade das situações jurídicas existenciais quando opostas aos interesses estritamente patrimoniais inviabiliza peremptoriamente que se opere eventual redistribuição dos danos e dos riscos. Nestas hipóteses, a ascendência da cláusula geral de tutela da dignidade humana predetermina o integral resguardo dos direitos da personalidade, em consideração às peculiaridades existenciais do indivíduo ${ }^{155}$.

\section{5 - A constitucionalidade do dispositivo}

Finalmente, esgotando os esforços de esmiuçar o conteúdo do parágrafo único do artigo 944, cumpre dirigir-se à questão de sua constitucionalidade, a qual também é objeto de especulação doutrinária, havendo doutrinadores que defendam a incompatibilidade material da norma com os preceitos da Carta Maior.

O dispositivo tem uma delicada correlação com o princípio da reparação integral, preceito este que ganha sobrelevada importância no sistema de responsabilidade civil contemporâneo, a partir do giro conceitual que deslocou

\footnotetext{
${ }^{154}$ Id. Danos à Pessoa Humana, p. 304: "a dignidade da pessoa humana, sendo um fim, e não um meio, não se sujeita a ponderações. Se assim é, tampouco subordina-se a circunstâncias atenuantes ou excludentes, a relativizações de qualquer tipo, cabendo-lhe a predominância onde quer que se manifeste".

${ }^{155}$ PERLINGIERI, Pietro. Op. cit., p. 173 e seguintes.
} 
seu eixo da figura do ofensor e a culpa pelo prejuízo causado para a figura da vítima e a recomposição do dano injustamente sofrido ${ }^{156}$, e que ganhou status de princípio constitucional implícito, decorrente da inteligência do artigo $5^{\circ}$, incisos V e X, da Constituição da República ${ }^{157}$.

Reconhecido tal grau de destaque e relevância atribuído a restitutio in integrum, ora estabelecida como prioridade do sistema de responsabilidade civil, com atenção devem ser apreciadas as normas, tal como o parágrafo único do artigo 944, que tragam a possibilidade de se restringir o montante de verbas de ressarcimento. Caso se verifique que a norma representa uma violação ao princípio, deve ser tida como inconstitucional ${ }^{158}$. Entretanto, se apenas instituir uma hipótese excepcional à regra sistemática, deve ser considerada como parte integrante do ordenamento, portanto, constitucional, pois mesmo os princípios de fulcro constitucional não são absolutos e comportam ponderações, quando contrapostos uns aos outros ${ }^{159}$.

Nesta esteira, os que defendem a inconstitucionalidade do instituto o acusam de representar um ataque frontal e materialmente insustentável ao princípio da reparação integral ${ }^{160}$, representando a norma verdadeiro retrocesso

\footnotetext{
${ }^{156}$ MORAES, Maria Celina Bodin de. Danos à Pessoa Humana, p. 331: “A reparação integral parece ser a medida, necessária e suficiente, para proteger a pessoa humana nos aspectos que realmente a individualizam. De fato, considera-se que a responsabilidade civil na atualidade tem como foco precípuo a situação em que se encontra a vítima, visando recompor a violência sofrida em sua dignidade através da reparação integral do dano".

${ }^{157}$ CUNHA, Leonardo Nascimento. Op. cit., p. 02.

158 MORAES, Maria Celina Bodin de. Danos à Pessoa Humana, p . 333: "Em decorrência da tutela geral estabelecida em nível constitucional, a reparação do dano moral não poderá ser limitada, mediante a imposição de tetos, por legislação infraconstitucional, que, se anterior à Constituição, deverá ser considerada não recepcionada, e, se posterior, deverá ser tida por inconstitucional".

${ }^{159}$ BARROSO, Luís Roberto. Op. cit., p. 31: "em uma ordem pluralista, existem outros princípios que abrigam decisões, valores ou fundamentos diversos, por vezes contrapostos. A colisão de princípios, portanto, não só é possível, como faz parte da lógica do sistema, que é dialético. Por isso a sua incidência não pode ser posta em termos de tudo ou nada, de validade ou invalidade" (grifos no original). E conclui: “A aplicação dos princípios se dá, predominantemente, mediante ponderação".

${ }^{160}$ CUNHA, Leonardo Nascimento. Op. cit. p. 06: "Vale dizer, não se pode conceber que, num evento em que o cidadão sofra um prejuízo de cunho material, possa o juiz abrandar a indenização devida diante da maior ou menor gravidade da culpa do autor do dano, sob pena de se malferir o princípio da restitutio in integrum, alçado, como detido, a patamar constitucional (art. $5^{\circ}$, V e X, da Magna Carta)". Paralelamente, o autor defende a constitucionalidade do dispositivo em sede de dano extrapatrimonial, dentro do espectro punitivo de sua compensação.
} 
em relação às conquistas no campo da responsabilidade civil em prol da tutela dos interesses da vítima ${ }^{161}$.

Entende-se, em suma, que o princípio da reparação integral, como expressão da dignidade humana, dada a sua extrema relevância para o sistema de responsabilidade civil contemporâneo - eis que o princípio ocupa justamente o âmago da atual dinâmica do direito de danos pátrio -, não comportaria exceções.

O parágrafo único do artigo 944 representaria um real obstáculo ao perfazimento da própria lógica do sistema, pois constituiria um óbice ao incondicional ressarcimento da vítima pelo dano injustamente sofrido.

Uma proposição desta natureza, imersa na atual concepção de ordenamento jurídico, centrada na cláusula geral de tutela da pessoa, não teria respaldo, estando o dispositivo, portanto, eivado de inconstitucionalidade, por inconformidade material aos preceitos fundamentais do ordenamento.

Em posição adversa, sustenta-se a constitucionalidade da norma ao lê-la, não como uma violação ao princípio da reparação integral, mas como uma exceção ao mesmo.

$\mathrm{Na}$ medida em que a restitutio in integrum tem status de princípio constitucional implícito, é necessário que a aplicação do dispositivo também se informe pela orientação de um outro preceito insculpido na tábua axiológica da Carta Maior, o qual, pelo mecanismo de ponderação de valores constitucionais, tornaria a norma aplicável aos olhos do sistema. Este princípio, como já afirmado, é a solidariedade social, que informa o sistema do direito de danos pátrio, conformando o processo de distribuição de ônus e riscos sociais, prioritariamente em favor da tutela da vítima; e, excepcionalmente, em prol de interesses do agente nocivo. As próprias características do dispositivo, aliás,

\footnotetext{
${ }^{161}$ Ibid. p. 06: "Seria, nessa hipótese, e como salientado, retroceder centenas de anos e apagarmos toda a evolução doutrinária, jurisprudencial e, em última e final instância, legislativa vivenciada pela responsabilidade civil".
} 
todas de caráter cerceador - somente se comporta interpretação restritiva; temse limitada a aplicabilidade à responsabilidade subjetiva e aos danos materiais; somente se toma como critério a excessiva desproporção entre grau de culpa do agente e a extensão do dano, não comportando nenhum outro elemento a se considerar para operar a redução; e a confiança, no caso concreto, ao prudente e fundamentado juízo equânime do magistrado -, contribuem para evidenciar a norma como preceito de aplicação residual, verdadeiramente excepcional, e, assim sendo, facilmente passível de harmonização com a lógica do sistema.

A norma, a despeito de quão acertada se julgue a escolha legislativa por erigi-la, não se confronta com o ordenamento, e sua inconstitucionalidade parece distante de ser decretada. Em verdade, a norma não apresenta nenhum ponto de tensão com a lógica do sistema, apenas uma previsão excepcional para circunstâncias extravagantes em que, em atenção ao princípio da solidariedade social, o juiz tenha fundamentos para operar equiitativa redução do montante indenizatório.

A reparação integral segue sendo a regra, o parágrafo único meramente traduz uma breve ressalva, uma exceção que pode ser evocada em determinadas dimensões fáticas, jamais um vilipêndio aos princípios que informam a tábua axiológica constitucional. Assim, ao invés de simplesmente refutá-la, devem procurar-se os meios para se operar a sua melhor adequação ao ordenamento ${ }^{162}$.

A chave para a constitucionalidade do disposto, afinal, reside em seu próprio caráter residual, decorrente da interpretação restritiva, que se impõe, e

\footnotetext{
162 Pela assaz síntese, permita-se uma última referência ao trabalho de KONDER, Carlos Nelson. A redução eqüitativa da indenização em virtude do grau de culpa: apontamentos acerca do parágrafo único do art. 944, do Código Civil. In: Revista Trimestral de Direito Civil, n. ${ }^{\circ}$ 29, jan/mar 2007. p. 30/31: "Ainda que se reconheça o caráter de princípio implícito à reparação integral do dano, é pouco provável que o judiciário venha a declarar inconstitucional uma mitigação deste princípio que não se apresenta como uma tarifação limitadora do montante indenizatório, mas apenas como uma abertura ao juízo de eqüidade do magistrado. Ainda que inconveniente e indesejado, o dispositivo é - e aparentemente continuará a ser - parte de nosso ordenamento e, portanto, é imperioso, de lege condenda, interpretá-lo em conformidade com a nossa ordem constitucional”.
} 
de sua excepcional aplicabilidade, devendo o magistrado, no caso concreto, fundamentar a utilização da norma nos ditames da solidariedade social. 


\section{Conclusão - Síntese de idéias e considerações finais}

"Há uma medida para tudo. Há limites além e aquém de que o justo não encontra morada." - Horácio (65 a.C. -8 a.C.);

O parágrafo único do artigo 944, inovação trazida pelo Código Civil de 2002, provocou perplexidade na doutrina. A inserção do instituto da culpa no processo de quantificação da indenização foi recebida com estranheza, dada a consolidada prática jurisprudencial, apoiada na doutrina nacional, de mensurar o montante reparatório exclusivamente com base no critério (de caráter objetivo) da extensão do dano. Ainda mais, o dispositivo também foi objeto de reservas por ressuscitar a discussão dos graus da culpa, distinção considerada infrutífera e superada por muitos civilistas.

A aparente desconformidade do dispositivo com as tendências de objetivação e ampliação das hipóteses de indenização do dano, em atenção às necessidades da vítima do prejuízo injustamente sofrido, incentivou a reavaliação do instituto da culpa, de sua função no campo da responsabilidade civil, do papel do próprio direito de danos no ordenamento pátrio, e, principalmente, impulsionou a discussão do conteúdo da nova norma, a qual não poderia ser simplesmente ignorada.

Tradicionalmente, o instituto da culpa sempre ocupou papel de destaque no sistema de responsabilidade civil. A despeito da recorrência e da relevância, a culpa sempre se provou um tópico espinhoso na dogmática, em função, inclusive, da marcante dificuldade que gira em torno de seu próprio conceito. Definir culpa provou-se uma tarefa doutrinariamente demandante. Incontáveis formulações foram elaboradas, mas o conceito permaneceu por muito tempo enevoado. Contemporaneamente, encaminha-se a doutrina, finalmente, para a superação desta dificuldade, pela assimilação definitiva do conceito normativo (ou objetivo) de culpa, definindo-a como um erro de conduta, considerado a 
partir de um padrão subjetivado de comportamento social, que produz efeitos nocivos à esfera de direitos patrimoniais e extrapatrimoniais de outrem.

Este conceito de culpa divide-se em duas espécies, o dolo, hipótese em que há deliberada intenção de provocar o resultado lesivo, e a culpa em sentido estrito, em que, embora não haja o animus nocendi, a conduta, por negligência ou imprudência do agente, está em desconformidade com os parâmetros de diligência socialmente esperados, os quais, se adotados, obstariam a ocorrência dos efeitos danosos.

Admite-se a graduação da culpa em sentido estrito, comumente se a dividindo em culpa grave (ou lata), leve e levíssima, a depender do grau de desvio a ser considerado, na conduta do agente, em referência à expectativa social de comportamento. A culpa grave corresponde ao erro grosseiro, que a mínima diligência poderia evitar; a culpa leve, ao desvio que se combate pela ordinária diligência; a culpa levíssima, à conduta irregular que se encontra no limiar entre o comportamento reto e o desvirtuado, sendo necessária uma diligência maior para refreá-la.

A despeito de sua relevância histórica - tradicionalmente, o instituto da culpa sempre foi basilar ao sistema de responsabilidade civil, tendo, por séculos, atuado como quase exclusivo critério para a determinação do nexo de imputação do dever de indenizar -, a culpa passa, atualmente, por uma reavaliação. $\mathrm{O}$ direito privado sofreu grandes transformações, sobretudo a partir das últimas décadas do século XX, em razão da reestruturação de todo o ordenamento, a partir da tábua axiológica constitucional. Assim, também a responsabilidade civil tem a necessidade de revisitar os seus conceitos, entre eles a culpa, conformando-os à luz desta nova principiologia.

A transformação do ordenamento pátrio tem a promulgação da Carta Constitucional, em 05 de outubro de 1988, como marco inaugural de um novo momento da tradição jurídica brasileira, em que se reconhece a direta efetividade das normas constitucionais, inclusive a de seus princípios, os quais 
devem ser tidos como diretrizes à formulação, interpretação e aplicação das normas infraconstitucionais, mesmo as de direito privado.

A ascendência da axiologia da carta constitucional, sobretudo a exortação da dignidade humana e a solidariedade social, implicou em verdadeira virada no direito de danos, tendo a responsabilidade civil deslocado o seu eixo da culpa do agente pelo dano causado, abandonando sua função estritamente moralizadora, para a reparação da vítima pelo dano injustamente sofrido, reconhecendo-se no sistema um novo papel, o de divisor e distribuidor de riscos e ônus sociais. Conseqüentemente, detectaram-se as tendências de erosão dos filtros da responsabilidade civil - entre eles, a culpa - e de ampliação das hipóteses de dano indenizável.

Nesta perspectiva, a reparação integral, decorrente da cláusula geral de tutela da dignidade da pessoa, ganhou sobrelevada importância, pois determina que, no melhor interesse da vítima, deve recompor-se o seu estado ao patamar precedente ao da ocorrência do evento danoso, ao máximo possível. Trazendo exceção a este princípio, o parágrafo único provou-se, de início, uma norma de que se deveria tratar com maiores cuidados.

Em síntese, o parágrafo único do artigo 944 do Código Civil de 2002 permite a redução do montante indenizatório, no caso concreto, ao diligente e fundamentado arbítrio do juiz, com fulcro na eqüidade, quando houver excessiva desproporção entre o grau de culpa do agente e a extensão do dano. O princípio constitucional a orientar a aplicação do dispositivo deve ser a solidariedade social, a partir do reconhecimento do novo papel de divisor e distribuidor de riscos e ônus da vida em coletividade, desempenhado pelo sistema de responsabilidade civil no ordenamento jurídico brasileiro. Afinal, reduzir as verbas indenizatórias implica impor à vítima o compartilhamento de parcela dos ônus do evento danoso.

Da dicção do dispositivo é importante salientar que o legislador claramente procurou enfatizar seu caráter excepcional, reservando-o às 
hipóteses de excessiva desproporção entre a gravidade de culpa do agente e as dimensões do prejuízo, eliminando a adoção de outros critérios, tais como as condições sócio-econômicas de ambos ofensor e ofendido. Ainda mais, confiou ao juízo equânime (e fundamentado) do magistrado a possibilidade da redução.

Pelo evidente caráter de exceção à regra geral, que permanece sendo a reparação integral, nos moldes da dimensão do dano, preconiza-se a interpretação restritiva do disposto, evidenciada pela estrutura caput-parágrafo, em atenção às regras da hermenêutica jurídica. Obstadas, portanto, restam as tendências de se interpretar o dispositivo extensivamente, incluindo outros critérios a autorizar a redução do montante indenizatório, ou de se valer de leitura em sentido reverso, para permitir a ampliação das verbas reparatórias em hipóteses de dolo ou de significativa gravidade de culpa, conferindo, desta maneira, à indenização, um cunho punitivo.

No que tange à aplicabilidade do dispositivo, ele se restringe às hipóteses de responsabilidade civil subjetiva e de danos patrimoniais. $\mathrm{Na}$ medida em que a norma se dispõe a operar remanejamento dos riscos sociais, não há razão de ser evocada no terreno da responsabilidade civil objetiva, em que o fundamento, justamente, é o elevado incremento do risco de produção de danos, a ponto de se desvincular o nexo de imputação da caracterização da culpa. Nas lesões extrapatrimoniais, também descabe a possibilidade de redução, pois contrapostos estão o interesse patrimonial do ofensor e um direito da personalidade do ofendido. Nestas hipóteses, os últimos sempre terão preponderância, devendo atentar-se à cláusula geral de dignidade da pessoa, que impõe a prevalência das situações jurídicas existenciais quando opostas a interesses estritamente materiais.

A despeito de oferecer uma limitação à reparação integral, princípio constitucional implícito, não há que se questionar a constitucionalidade do parágrafo único do artigo 944. A aplicação do dispositivo se deve orientar pelo 
princípio da solidariedade social, o qual também compõe a tábua axiológica da constituição. Não se trata de uma violação do princípio da reparação integral, mas de uma mera exceção, a ser utilizada apenas em circunstâncias residuais, permitindo, desta maneira, facilmente se operar a harmonização do preceito ao ordenamento, pela ponderação de princípios da solidariedade social e da reparação integral.

Portanto, ao invés de condenar o dispositivo, acusando-lhe de provocar um retrocesso jurídico inaceitável, mais vale interpretá-lo de maneira positiva, dando-lhe uma roupagem compatível com a axiologia do ordenamento. Da mesma forma que não se deve privar a norma de uma interpretação proveitosa, tampouco se lhe deve atribuir significação que esteja para lá de seu conteúdo. A indenização punitiva pode ser um tema importante na contemporaneidade do direito civil brasileiro e que demanda urgência em seu tratamento pela doutrina e pelo legislativo, mas não compete, em razão desta premência, aos juristas, avançar sobre qualquer dispositivo legal, distorcendo-o grotescamente, apenas para apresentar um arremedo de sustentáculo normativo a uma doutrina que ainda não encontrou guarida nos diplomas legais.

Dê-se à norma, em suma, o papel que a ela compete, nem mais, nem menos. É o que se deve e, também, apenas o que se pode fazer. 


\section{BIBLIOGRAFIA}

AMARAL, Francisco. Direito Civil: Introdução. $6^{\mathbf{a}}$ Ed. Rio de Janeiro: Renovar, 2006. 672 p.

BANHOZ, Rodrigo Pelais e FACHIN, Luiz Edson. Crítica ao legalismo jurídico e ao historicismo positivista: ensaio para um exercício de diálogo entre história e direito, na perspectiva do Direito Civil contemporâneo. In: RAMOS, Carmem Lucia Silveira et al (Orgs.). Diálogos sobre Direito Civil: construindo uma racionalidade contemporânea. Rio de Janeiro: Renovar, 2002. p. 47 - 74. BARROSO, Luís Roberto. Fundamentos Teóricos e Filosóficos do Novo Direito Constitucional Brasileiro (Pós-modernidade, teoria crítica e póspositivismo). In: BARROSO, Luís Roberto (Org.). A nova interpretação constitucional: Ponderação, direitos fundamentais e relações privadas. Rio de Janeiro: Renovar, 2003. p. $01-48$.

BITTAR, Carlos Alberto e FILHO, Carlos Alberto Bittar. A constituição de 1988 e o direito civil: os novos princípios fundamentais para o relacionamento privado. In: BITTAR, Carlos Alberto e FILHO, Carlos Alberto Bittar. Direito Civil Constitucional. $3^{\text {a }}$ Ed. São Paulo: Revista dos Tribunais, 2003. p. 17 - 30. A Questão da Interpretação no Direito Civil. In: BITTAR, Carlos Alberto e FILHO, Carlos Alberto Bittar. Direito Civil Constitucional. $3^{\mathrm{a}}$ Ed. São Paulo: Revista dos Tribunais, 2003. p. $31-44$.

CASTRO, Carlos Roberto Siqueira. Dignidade da pessoa humana: o princípio dos princípios constitucionais. In: GALDINO, Flavio e SARMENTO, Daniel (Orgs.). Direitos Fundamentais: Estudos em homenagem ao Professor Ricardo Lôbo Torres. p. 135 - 179.

CRUZ, Gisela Sampaio da. O Problema do Nexo Causal na Responsabilidade Civil. Rio de Janeiro: Renovar, 2005. 388 p.

CUNHA, Leonardo Nascimento. A aplicabilidade do art. 944, parágrafo único, do Código Civil de 2002 aos danos materiais. Disponível em 
http://jus2.uol.com.br/doutrina/texto.asp?id=9568. Acesso em 19 de outubro de 2007.

DAHMER, André. Breve Fábula da Culpa Alheia. Disponível em http://www.malvados.com.br. Acesso em 12 de outubro de 2007.

DIAS, José de Aguiar. Da Responsabilidade Civil. vol. I. $7^{\mathrm{a}}$ Ed. Rio de Janeiro: Forense, 1983. 387 p.

DIREITO, Carlos Alberto Menezes e FILHO, Sérgio Cavalieri. Da responsabilidade civil, das preferências e privilégios creditórios: arts. 927 a 965. In: TEIXEIRA, Sálvio de Figueiredo. Comentários ao Novo Código Civil. vol. XIII. Rio de Janeiro: Renovar, 2004. 555 p.

FACHIN, Luiz Edson. Transformações do Direito Civil Brasileiro Contemporâneo. In: RAMOS, Carmen Lucia Silveira et al. (Orgs.). Diálogos sobre Direito Civil: construindo uma racionalidade contemporânea. Rio de Janeiro: Renovar, 2002. p. 41 - 46.

- Direito Civil e dignidade da pessoa humana: um diálogo constitucional contemporâneo. In: Revista Forense, vol. 102, n. ${ }^{\circ}$ 385, mai/jun 2006, p. $113-125$.

. O Futuro da Codificação e o Jurista do Amanhã; Idéias para um Debate. In: Revista da EMERJ, vol. 7, n. ${ }^{\circ}$ 26, abr/jun 2004, p. 115 - 124.

. Fundamentos, Limites e Transmissibilidade: Anotações para uma

Leitura Crítica, Construtiva e de Índole Constitucional da Disciplina dos Direitos da Personalidade no Código Civil Brasileiro. In: Revista da EMERJ, vol. 8, n. $^{\text {o }} 31$, jul/set 2005 , p. $51-70$.

FACHIN, Luiz Edson e RUZYK, Carlos Eduardo Pianovski. Um Projeto de Código Civil na contramão da Constituição. In: Revista Trimestral de Direito

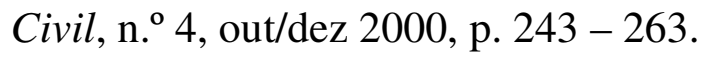

FERREIRA, Aurélio Buarque de Holanda. Novo Dicionário da Língua Portuguesa. $1^{\text {a }}$ Ed. Rio de Janeiro: Nova Fronteira, 1971. 1499 p. 
FILHO, Sergio Cavalieri. Programa de Responsabilidade Civil. $5^{\mathrm{a}}$ Ed. $2^{\mathrm{a}}$ Tiragem. São Paulo: Malheiros Editores, 2004. 559 p.

FINGER, Julio César. Constituição e direito privado: algumas notas sobre a chamada constitucionalização do direito civil. In: SARLET, Ingo Wolfgang (Org.). A Constituição Concretizada: Construindo pontes com o público e o privado. Porto Alegre: Livraria do Advogado, 2000. p. 85 - 106.

FIÚZA, Ricardo (Coord.). Novo Código Civil Comentado. $4^{\mathrm{a}}$ Ed. São Paulo: Saraiva, 2005. 1904 p.

GONÇALVES, Carlos Roberto. Responsabilidade Civil. 9a Ed. São Paulo: Saraiva, 2005. $966 \mathrm{p}$.

GONÇALVES, Luiz da Cunha. Tratado de Direito Civil em Comentário ao Código Civil Português. vol. XII. Tomo II. São Paulo: Max Limonad, 1957.

GRECO, Rogério. Curso de Direito Penal. vol. I. Parte Geral: Artigos 1ª 120 do Código Penal. $7^{\text {a }}$ Ed. Rio de Janeiro: Impetus, 2006. 823 p.

KONDER, Carlos Nelson. A redução eqüitativa da indenização em virtude do grau de culpa: apontamentos acerca do parágrafo único do art. 944, do Código Civil. In: Revista Trimestral de Direito Civil, vol. 29, jan/mar 2007, p. 03 - 34. LÔBO, Paulo Luiz Netto. Danos morais e direitos da personalidade. Disponível em http://jus2.uol.com.br/doutrina/texto.asp?id=4445. Acesso em 16 de outubro de 2007.

LOTUFO, Renan. Da oportunidade da Codificação Civil e a Constituição. In: SARLET, Ingo Wolfgang (Org.). O Novo Código Civil e a Constituição. Porto Alegre: Livraria do Advogado, 2003. p. 11 - 30.

MATTIETTO, Leonardo. O Direito Civil Constitucional e a Nova Teoria dos Contratos. In: TEPEDINO, Gustavo (Coord.). Problemas de Direito CivilConstitucional. Rio de Janeiro: Renovar, 2000. p. 163 - 186.

MAXIMILIANO, Carlos. Hermenêutica e aplicação do direito. $18^{\mathrm{a}} \mathrm{Ed}$. Rio de Janeiro: Forense, 1999. 426 p. 
MELGARÉ, Plínio Saraiva. Um olhar sobre os direitos fundamentais e o Estado de direito - breves reflexões ao abrigo de uma perspectiva material. In: CRUZ, Danielle da Rocha e FILHO, Agassiz de Almeida (Coords.). Estado de direito e direitos fundamentais: homenagem ao jurista Mário Moacyr Porto. Rio de Janeiro: Forense, 2005. p. 573 - 590.

MIRANDA, Francisco Pontes. Tratado de Direito Privado. vol. XXIII. Rio de Janeiro: Borsói, 1958. 503 p.

MORAES, Maria Celina Bodin de. Danos à Pessoa Humana: Uma Leitura Civil-Constitucional dos Danos Morais. Rio de Janeiro, Renovar, 2003. 356 p. Apresentação. In: MORAES, Maria Celina Bodin de (Coord.). Princípios do Direito Civil Contemporâneo. Rio de Janeiro: Renovar, 2006. p. $\mathrm{v}-\mathrm{xii}$.

O Princípio da Dignidade Humana. In: MORAES, Maria Celina Bodin de (Coord.). Princípios do Direito Civil Contemporâneo. Rio de Janeiro: Renovar, 2006. p. $01-60$.

- O conceito de dignidade humana: substrato axiológico e conteúdo normativo. In: SARLET, Ingo Wolfgang (Org.). Constituição, Direitos Fundamentais e Direito Privado. Porto Alegre: Livraria do Advogado, 2002. p. 105 - 147.

. O Princípio da Solidariedade. In: PEIXINHO, Manoel Messias et al. (Orgs.). Os Princípios da Constituição de 1988. Rio de Janeiro: Lúmen Júris, 2001. p. 167 - 190.

A Caminho de um direito civil constitucional. In: Revista de Direito Civil, Imobiliário, Agrário e Empresarial, vol.17, n. ${ }^{o}$ 65, jul/set 1993. p. $21-32$.

Constituição e direito civil: tendências. In: Revista dos Tribunais, vol. 89 , n. ${ }^{\text {o } 779}$, set 2000 , p. $47-63$. 
A constitucionalização do direito civil e seus efeitos sobre a responsabilidade civil. In: Direito, Estado e Sociedade, vol. 09, n. ${ }^{\text {2 } 29, \text { jul/dez }}$ 2006 , p. $233-256$.

- Punitive Damages em sistemas civilistas: problemas e perspectivas. In: Revista Trimestral de Direito Civil, vol. 18, abr/jun 2004, p. $45-78$.

NETO, Eugênio Facchini. Da responsabilidade civil no novo Código. In: SARLET, Ingo Wolfgang (Org.). O Novo Código Civil e a Constituição. Porto Alegre: Livraria do Advogado, 2003. p. 151 - 198.

NEVES, Gustavo Kloh Muller. Os princípios entre a teoria geral do direito e o Direito Civil Constitucional. In: RAMOS, Carmen Lucia Silveira et al. (Orgs.). Diálogos sobre Direito Civil: construindo uma racionalidade contemporânea. Rio de Janeiro: Renovar, 2002. p. 03 - 21.

PEREIRA, Caio Mário da Silva. Instituições de Direito Civil. vol. I. Introdução ao Direito Civil, Teoria Geral do Direito Civil. Atualização por MORAES, Maria Celina Bodin de. 20a Ed. Rio de Janeiro: Forense, 2003. 718 p. . Instituições de Direito Civil. vol. II. Teoria Geral das Obrigações. Atualização por GAMA, Guilherme Calmon Nogueira da. $21^{\mathrm{a}}$ Ed. Rio de Janeiro: Forense, 2007. 472 p.

Instituições de Direito Civil. vol. III. Contratos, Declaração Unilateral de Vontade, Responsabilidade Civil. Atualização por FICHTNER, Régis. 12a Ed. Rio de Janeiro: Forense, 2005. 604 p.

Responsabilidade Civil. 9ª Ed. Rio de Janeiro: Forense, 1999. $350 \mathrm{p}$.

PERLINGIERI, Pietro. Perfis do Direito Civil: Introdução ao Direito Civil Constitucional. Tradução de Maria Cristina de Cicco. $3^{a}$ Ed. Rio de Janeiro, Renovar: 2007.359 p.

SARLET, Ingo Wolfgang. Direitos Fundamentais e Direito Privado: algumas considerações em torno da vinculação dos particulares aos direitos 
fundamentais. In: SARLET, Ingo Wolfgang (Org.). A Constituição Concretizada: Construindo pontes com o público e o privado. Porto Alegre: Livraria do Advogado, 2000. p. 107 - 163.

SARMENTO, Daniel. A trajetória da dicotomia público/privado. In: Revista

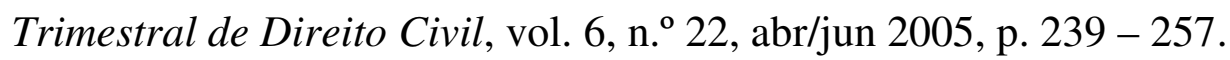

SCHREIBER, Anderson. Novas Tendências da Responsabilidade Civil Brasileira. In: Revista Trimestral de Direito Civil, vol. 6, n. . 22, abr/jun 2005, p. $45-69$.

SCHREIBER, Anderson e TEPEDINO, Gustavo. As Penas Privadas no Direito Brasileiro. In:GALDINO, Flávio e SARMENTO, Daniel (Orgs.). Direitos Fundamentais: Estudos em homenagem ao Professor Ricardo Lobo Torres. Rio de Janeiro: Renovar, 2006. p. 499 - 525.

STOCO, Rui. Tratado de Responsabilidade Civil. 6 ${ }^{\mathbf{a}}$ Ed. São Paulo: Revista dos Tribunais, 2004. 2203 p.

TEPEDINO, Gustavo. Premissas Metodológicas para a Constitucionalização do Direito Civil. In: TEPEDINO, Gustavo. Temas de Direito Civil. Tomo I. $3^{\text {a }}$ Ed. Rio de Janeiro: Renovar, 2004. p. 01 - 22.

. O Velho Projeto de um Revelho Código Civil. In: TEPEDINO, Gustavo. Temas de Direito Civil. Tomo I. $3^{\mathrm{a}}$ Ed. Rio de Janeiro: Renovar, 2004. p. $499-501$.

- O Novo Código Civil: duro golpe na recente experiência constitucional brasileira. In: TEPEDINO, Gustavo. Temas de Direito Civil. Tomo II. Rio de Janeiro: Renovar, 2006. p. 357 - 360.

. O Código Civil e o Direito Civil Constitucional. In: TEPEDINO, Gustavo. Temas de Direito Civil. Tomo I. Rio de Janeiro: Renovar, 2006. p. $377-378$.

O Código Civil, os chamados microssistemas e a Constituição: premissas para uma reforma legislativa. In: TEPEDINO, Gustavo (Coord.). 
Problemas de Direito Civil-Constitucional. Rio de Janeiro: Renovar, 2000. p. $01-16$.

Crise de fontes normativas e técnica legislativa na parte Geral do Código Civil de 2002. In: Revista Forense, vol. 98, n. ${ }^{\circ}$ 364, nov/dez 2002, p. $113-123$.

A incorporação dos direitos fundamentais pelo ordenamento brasileiro: sua eficácia nas relações jurídicas privadas. In: Ajuris, n. ${ }^{\circ}$ 100, dez 2005 , p. $153-167$.

. Normas Constitucionais e relações de direito civil na experiência brasileira. In: Boletim da Faculdade de Direito, stvdia ivridica n. ${ }^{\circ} 48$, colloquia n. ${ }^{\circ}$ 6. Separata de Conferências na Faculdade de Direito de Coimbra, 1999/2000, p. $323-345$.

TEPEDINO, Gustavo et al. Código Civil interpretado conforme a Constituição da República. vol. I. Rio de Janeiro: Renovar, 2004. 765 p.

- Código Civil interpretado conforme a Constituição da República. vol. II. Rio de Janeiro: Renovar, 2006. 909 p.

VARELA, João de Matos Antunes. Das Obrigações em Geral. vol. I. $7^{\text {a }}$ Ed. Coimbra: Almedina, 1991. 959 p.

Direito das Obrigações: conceito, estrutura e função da relação obrigacional, fontes das obrigações, modalidades das obrigações. Rio de Janeiro, Forense, 1977. 303 p.

VENOSA, Silvio de Salvo. Direito Civil. vol. I. Parte Geral. $3^{\text {a }}$ Ed. São Paulo: Atlas, 2003. 663 p.

. Direito Civil. vol. II. Teoria Geral das Obrigações e Teoria Geral dos Contratos. $3^{\text {a }}$ Ed. São Paulo: Atlas, 2003. 636 p. 